"نشريه علوم زراعى ايران"

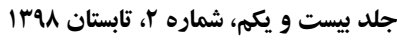

مقاله بزوهشى

اثر زمان كاشت و تراكم بوته بر رشد و عملكرد دانه دو اكوتيب كوار (Cyamopsis tetragonoloba L.)

\title{
Effect of sowing time and plant density on growth and seed yield of two guar ecotypes (Cyamopsis tetragonoloba L.)
}

$$
\text { مريم مهدى بور افرا'، مجيد آقاعليخانى '، على مختصى بيد كلى بَّ سعيدصوفى زاده }
$$

$$
\text { جكيده }
$$

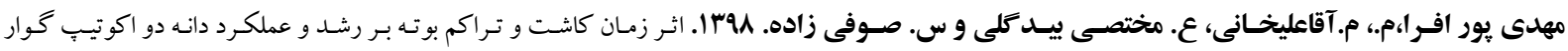
(Cyamopsis tetragonoloba L.)

به منظور ارزيابى طول دوره رشد و عملكرد دانه دو اكوتيب كوار در هاسخ به زمان كاشت و تراكم بوته، آزمايش مزرعسهاى بــــ صورت كرتهاى خرد شده - فاكتوريل در قالب طرح بلوككهاى كامل تصادفى با سه تكرار در سـال وهبا در دانشـكده كثـاورزى دانشعاه تربيت مدرس اجرا شد. تيمارهاى آزمايشى شامل جهار تاريخ كاشت (اول و 10 خرداد، اول و 10 تير) در كرتهاى

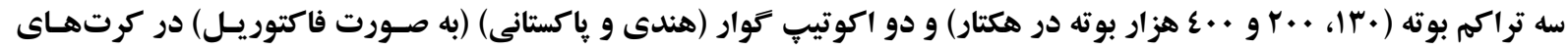
فرعى مورد ارزيابى قرار كرفتند. نتايج نشان داد كه در تاريخ كاشت اول خرداد و تراكم • ·ाا هزار بوته در هكتار، بيشترين عملكـرد

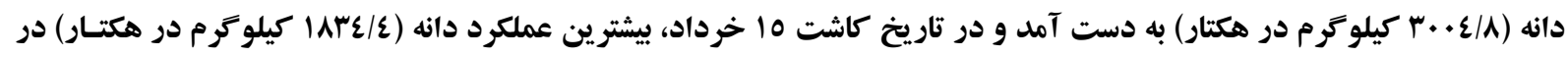

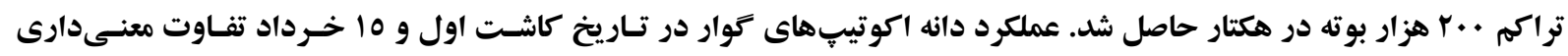

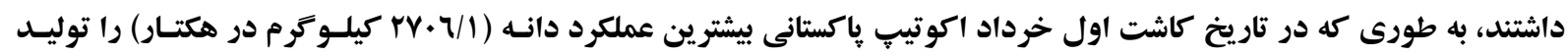

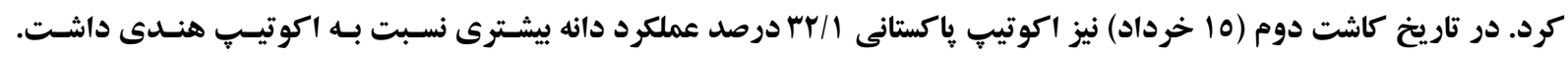

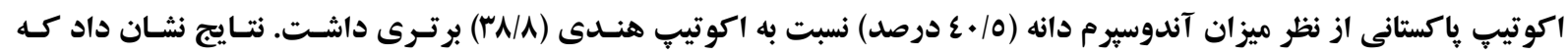

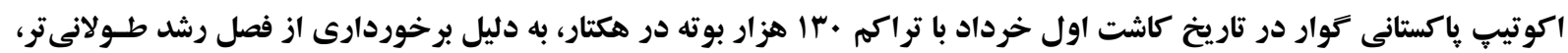
ارتفاع بوته و ماده خشكك بيشترى داشته و ضمن توليد غلاف و وزن هزار دانه بيشتر، عملكـرد دانسه بيشـترى نسـبت بـهـ سـاير تيمارهـا

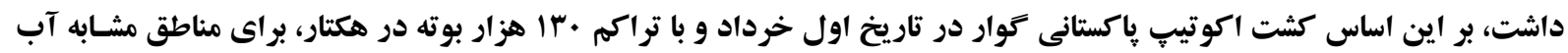
و هواى كرج مناسب به نظر مىرسد.

وازههاى كليدى: آندوسير مدانه، صمغ كوار، فواصل بوته، لوبياى خوشهاى و وزن هزار دانه.

\footnotetext{
اين مقاله مستخرج از رساله دكتر نگًارنده اول مىباشد.

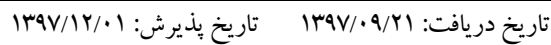
1- إنشجوى دكترى زراعت دانشكاه تربيت مدرس r- استاد دانشكده كشاورزى دانشكاه تربيت مدرس (مكاتبه كنده) (پيست الكترونيك:

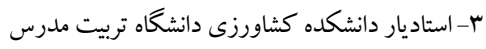
F- استاديار يزٔوهشكده علوم محيطى دانشكاه شهيد بهشتى دانس
} 


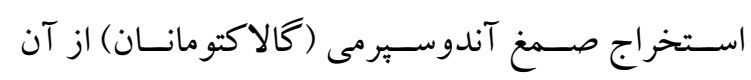

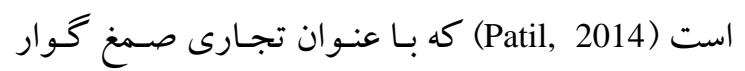
شـناخته مسىشـود (Guar gum) كاربردهاى صنعتى متنسوعى از صـمغ كـوار را مسىتـوان

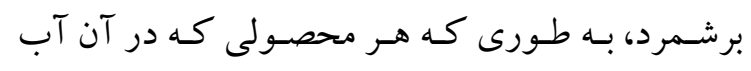

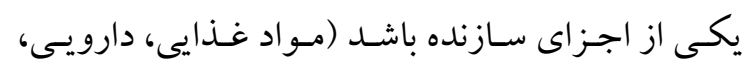

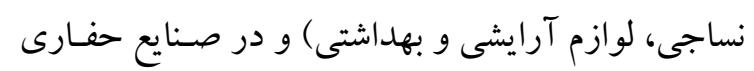

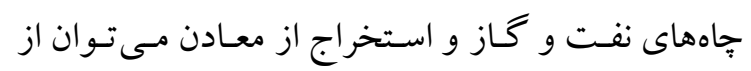

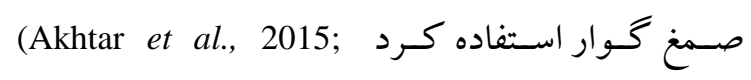
Eldirany et al., 2015; Sharma et al., 2014) از صمغ كوار بهعنوان جسـباننده در صـنايع يتروشـيمى، اين صنعت را متحول كرده و باعث افزايش قابل توجهى صنى

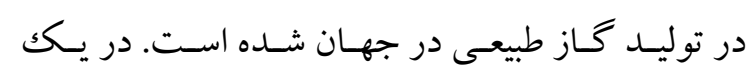

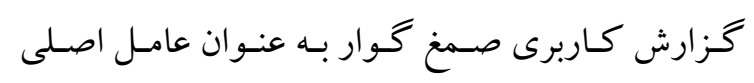
افزايش روز افزون تقاضـاى جهانى معرفى شـده اسـت

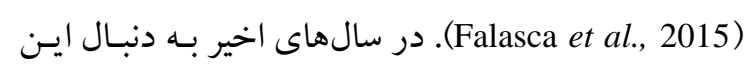

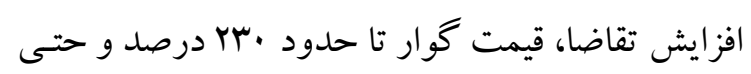
بيشتر افزايش يافته اسـت (Gresta et al., 2013). كنجاله كوار نيز كه محصول جـانبى فر آينـد استخر اج صسمغ از

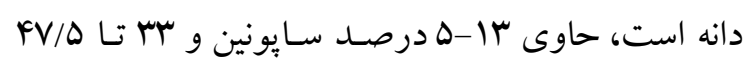
درصد يروتئين خام اسـت كـه مسىتـوان از آن در جيـره غذيى دام و طيور استفاده كرد (Hassan et al., 2008). تـاكنون تحقيقـات انسدكى در مـورد گيـاه گـوار در ايران انجام شده و معرفى آن براى شروع كشـت و كـار

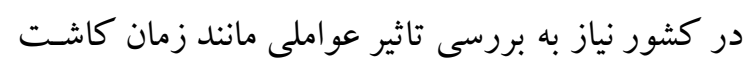

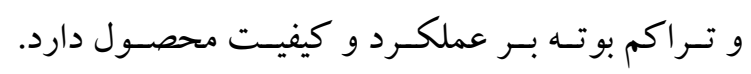
اصولا زمان كاشت هر كياه زراعى با توجه به رقم مـورد

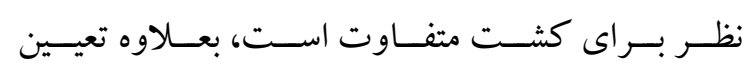

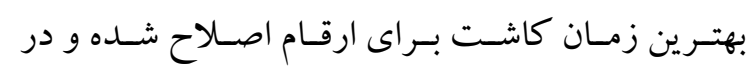

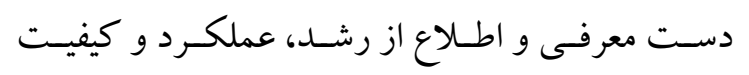

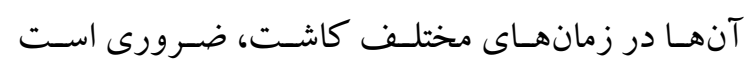

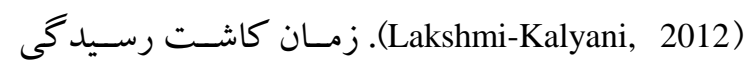

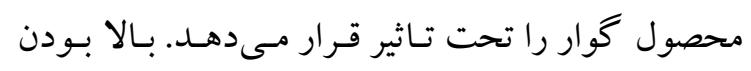
ميانگين دماى هوا در طول فصل رشـد، طول روزهـاى

\section{مقدمه}

ايران كشورى خشكك و نيمـه خشكك اسـت كـه در طى سالهاى اخير مشكل كم آبى آن حادتر شـده و ايـن مشكل هر ساله توليد كياهان زراعى را تحت تـاثير قرار

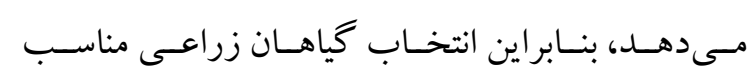
و استفاده از روشهاى صحيح مديريت زراعى مى تواند

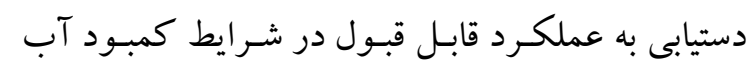

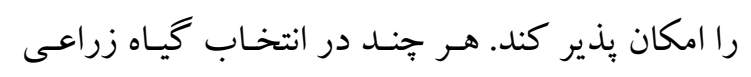
مناسـب بــراى كشـت هــاى تابسـتانه و داراى قابليـت تناوب با غـلات يـاييزه، محسدوديت وجـود دارد. گَـوار [Cyamopsis tetragonoloba L. (Taub.)]

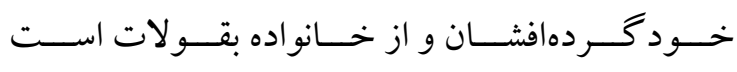
(Akhtar et al., 2015) شناخته مىشود. اين كياه زراعى با عادت رشـدى سـريع

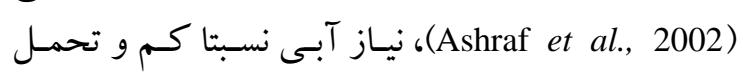
خـوب در برابـر تسنش كـم آبسى (Gendy et al., 2013)

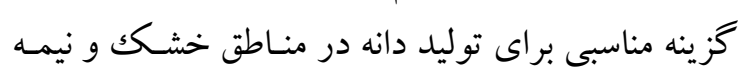

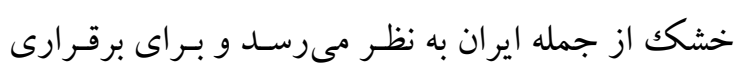
يكك نظام زراعت كم نهاده قابل استفاده است. با توجه به نه نيه توانايى تثبيت زيستى نيتروزن، گوار مانند اكثر بقـولات يكساله، كياه مناسبى جهت بهبود حاصلخيزى خاكك نيـز محسوب مىشود (Lakshmi Kalyani, 2012) و بر همين اساس در تنـاوب بـا غـلات و گياهـان دانسه روغنسى كـهـ

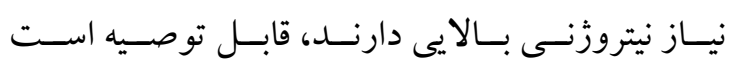

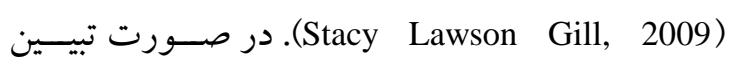
مناسبتهاى اكولوزيكك و سودمندىهـاى متعـدد كـوار براى نظامهـاى كشـاورزى و همجنـين مصـارف عمــده صنعتى و دارويى فر آوردههاى حاصل از دانه آن همـراه

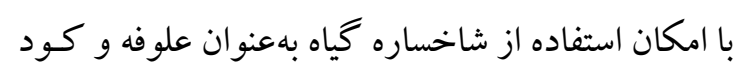
سبز (Eldirany et al., 2015) براى متخصصـين زراعـت، رويكرد بخش تحقيقات بايه براى كشت و بهرهبـردارى

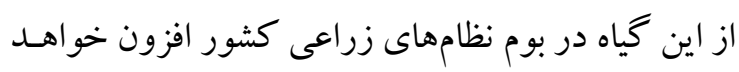
شد. ارزش تجـارى بــالاى دانسه خـــوار عمــدتا بـه دليـل 


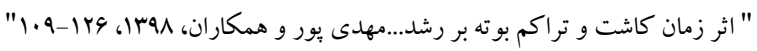

عملكـــد گالاكتومانـان در كـوار عمـــتا بـه تعـداد غلاف در بوته و عملكرد دانه وابسته اسـت. از ايـن رو

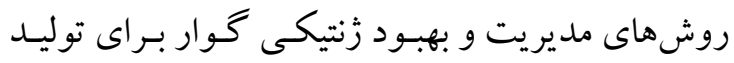

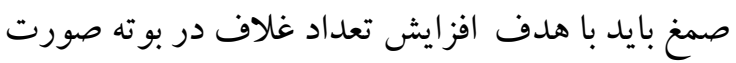

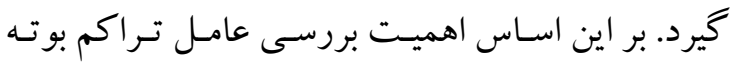
بيش از بيش مشخص مى شود، زيرا تراكم بوته بر تعـداد

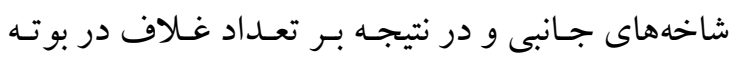

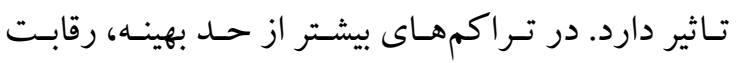

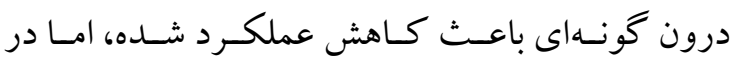

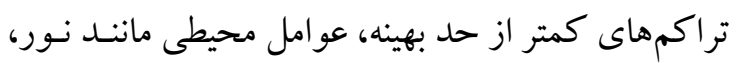

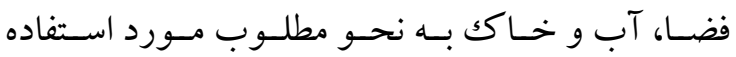

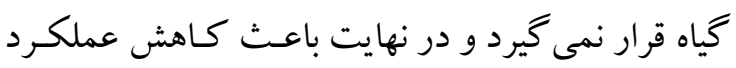

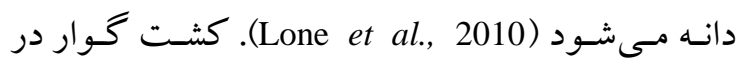

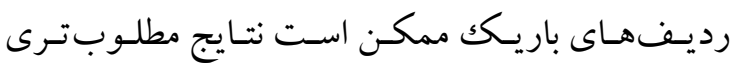

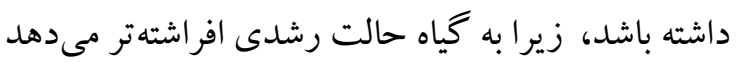
(Akhtar et al., 2012) با افزايش تـراكم بوتـه، فواصل

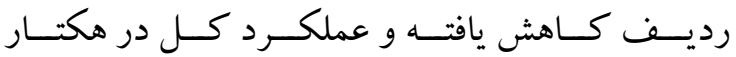
افـزايش مسىيابـد، بنـابراين، افـزايش تعـداد بوتسه در واحد سطح، مىتوانـد كـاهش تعـداد غـلافهـاى بوتسهـ

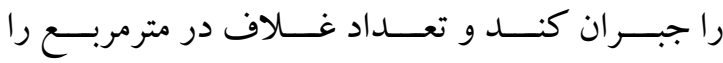
افزايش دهــ (Deka et al., 2015). رخحان و همكـاران كز ارش كردند كـه بين عملكـرد (Regan et al., 2003) دانه نخود و تراكم بوته رابطه مثبت و معنسدارى وجـود داشته و دليل عملكرد دانه در تراكمهاى بالاتر را تعـداد

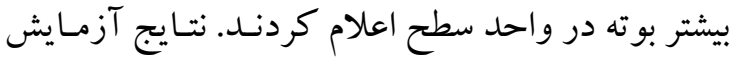

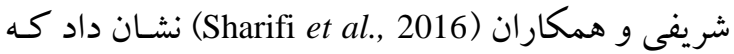
با افزايش تراكم بوته باقلا از ^ به ول1 بوتسه در متـر مربـع عملكرد دانه بهو درصد افزايش يافت.

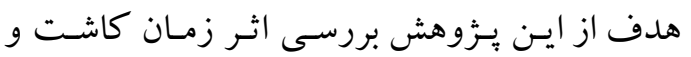

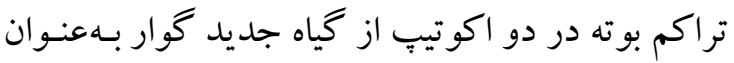

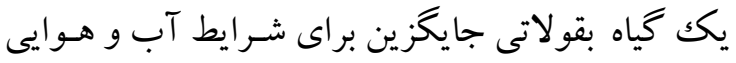

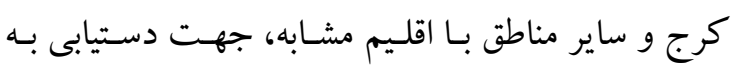
بالاترين عملكرد و كيفيت دانه بود.
بلنــد و آب و هـواى خشـك، باعـث افـز ايش سـرعت

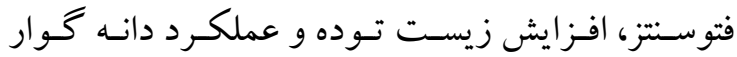

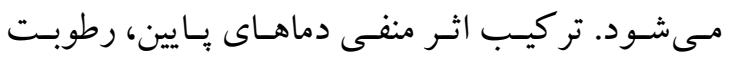

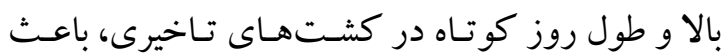

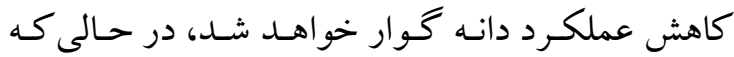

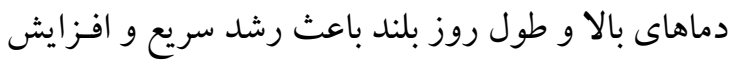

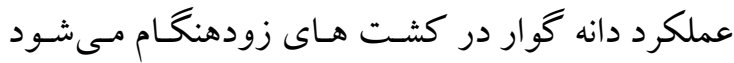

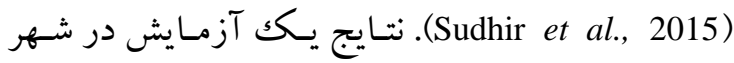

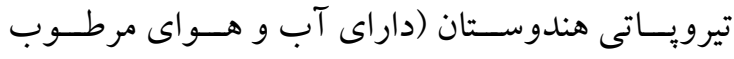

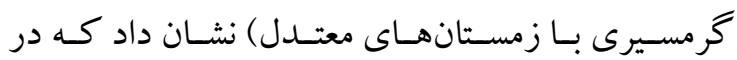
زمانهاى مختلف كاشت (هفته اول، دوم، سوم و جهارم

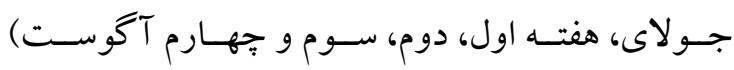

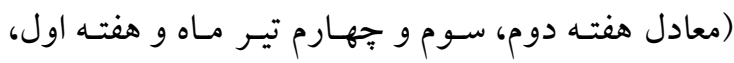

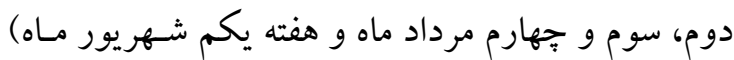

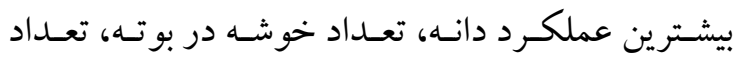
غلاف در خوشه، تعداد غـلاف در بوتـه، تعـداد دانه در غلاف، عملكرد صمغ خام و عملكرد يـروتئين خـام در

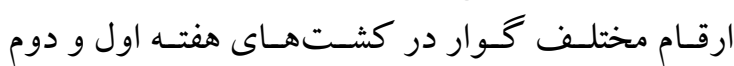
جولاى (معادل هفته دوم و سوم تير ماه) بـه دسـت آمـــ

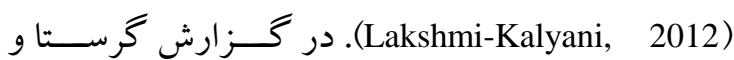
همكاران (Gresta et al., 2013)، اثر زمانهاى كاشـت V)

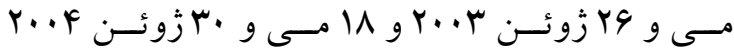

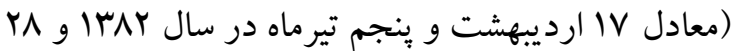
ارديبهشت و نهم تير ماه در سال سمشا) بر عملكـرد دانهـ

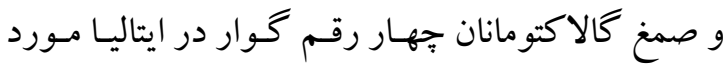

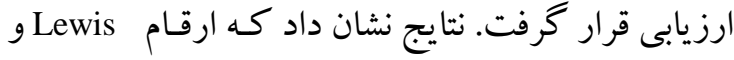

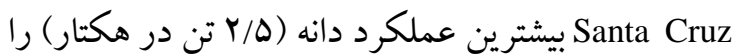
داشتند و عملكرد دانه گوار در كاشـت زودهنگ

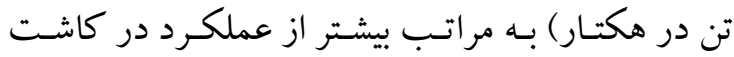

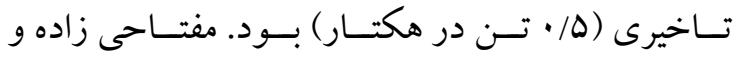

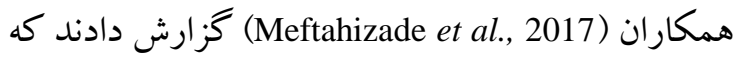
در شرايط آب و هـوايى ايـلام، عملكـرد دانه گكوار در

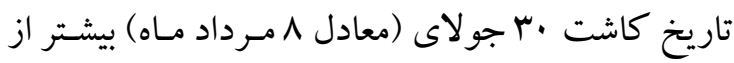
ها جولاى (معادل FF تيرماه) بود. 
سـالانه داراى آب و هـواى نيمهخشك بـوده و متوسط

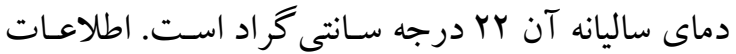
آب و هو ايى (بارش، دماى كمينه و دماى بيشينه) فصل

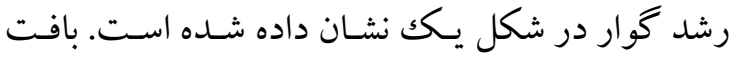

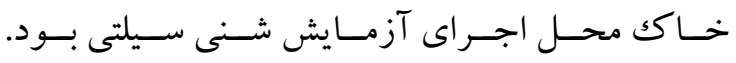

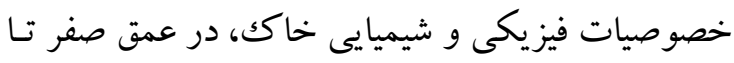

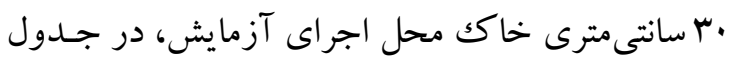
ارائه شده است.

\section{مواد و روشها}

ايسن آزمـايش طـى بهـار و تابستان سـال هوها درو

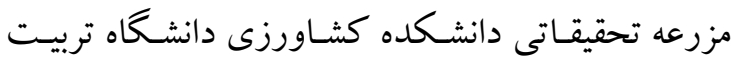

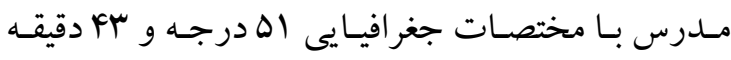
طول شرقى، هب درجه و \ دقيقه عرض شمالى و ارتفـاع

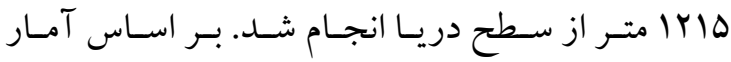

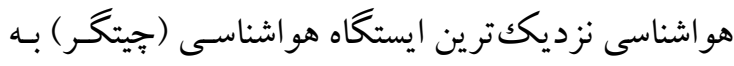

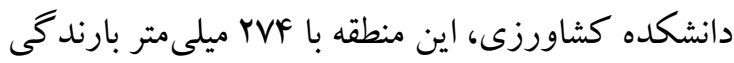

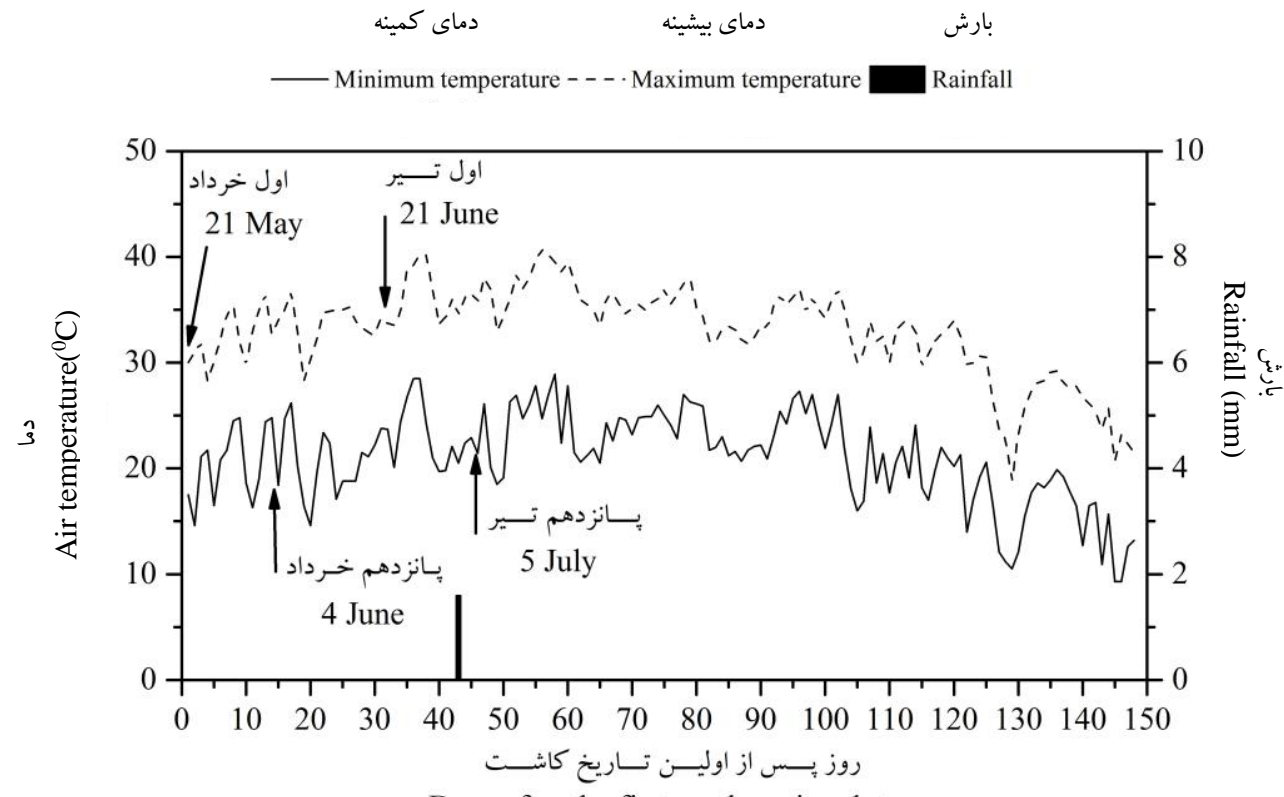

Days after the first seed sowing date

شكل 1-بارش، دماى كمينه و دماى بيشينه هواى محل اجر ایى آزمايش در طول فصل رشد (هوسا)

Fig. 1. Rainfall, minimum and maximum air temperature during growing season at experimental site (2016)

رديف؛ ها، ·لو ها سانتى متر و فاصـله بـين رديـف •0 سانتى متر ايجاد شدند.

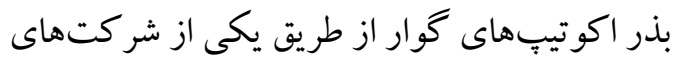

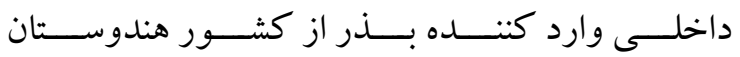
تامين شـــ. بـر اسـاس (Nufield Genetics PVT. LTD)

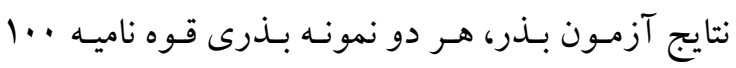

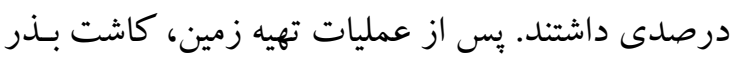

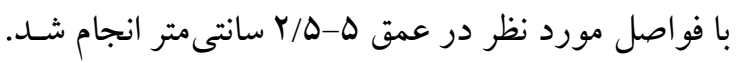

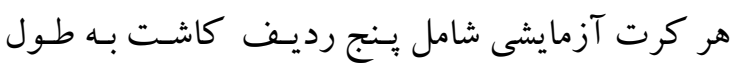

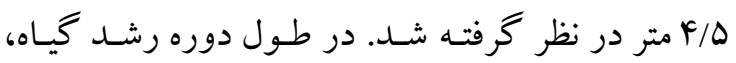

آزمايش به صورت كرتهاى خرد شده- فاكتوريل در قالب طرح بلو ككهاى كامـل تصـادفى بـا سـه تكـرار انجام شد. تيمارهاى آزمايشى شامل جهار تاريخ كاشت فالت

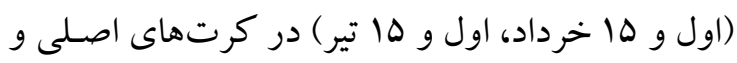

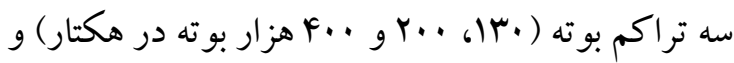

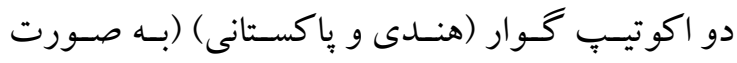
فاكتوريـل) در كرتهــاى فرعسى مـورد ارزيـابى قـرار

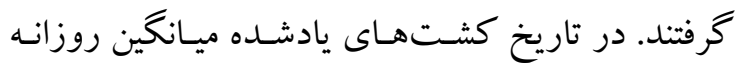

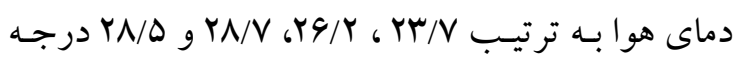

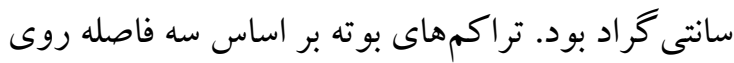




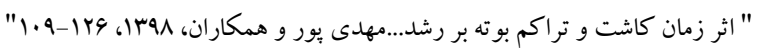

جدول ا- خصوصيات فيزيكى و شيميايى خاكك محل اجراى آزمايش

Table 1. Physical and chemical properties of the soil at experimental site

\begin{tabular}{|c|c|c|c|}
\hline $\begin{array}{c}\text { خصوصيات فيزيكى } \\
\text { Physical properties }\end{array}$ & Clay (\%) & 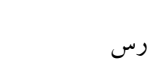 & 16 \\
\hline \multirow{10}{*}{$\begin{array}{c}\text { خصو صيات شيميايىى } \\
\text { Chemical properties }\end{array}$} & Sand $(\%)$ & 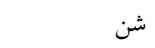 & 60 \\
\hline & Silt $(\%)$ & سيلت & 24 \\
\hline & $\mathrm{EC}\left(\mathrm{dS} \cdot \mathrm{m}^{-1}\right)$ & هدايت الكتريكح & 1.13 \\
\hline & $\mathrm{pH}$ & & 7.37 \\
\hline & T.N.V (\%) & مواد خنثى شوند & 6.5 \\
\hline & Organic carbon $(\%)$ & كربن آلى & 1.28 \\
\hline & Organic matter $(\%)$ & ماده آلى & 2.21 \\
\hline & Total N (\%) & نيتروزن & 0.13 \\
\hline & $\mathrm{P}\left(\mathrm{mg} \cdot \mathrm{kg}^{-1}\right)$ & فسفر & 77 \\
\hline & $\mathrm{K}\left(\mathrm{mg} \cdot \mathrm{kg}^{-1}\right)$ & يتاسيم & 412 \\
\hline
\end{tabular}

خشك بو تهها (بركَ، ساقه، غلاف و دانه) تعين شـده و بس از جدا كردن دانهها از غلاف، عملكرد دانه محاسبه

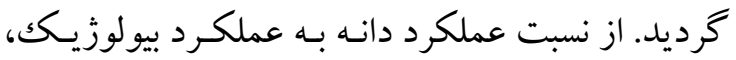
شاخص برداشت محاسبه شد.

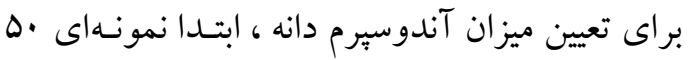

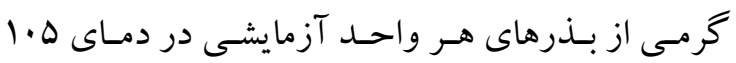
درجه سانتيگر اد به مدت شش ساعت در آون خشكانده شده، سيس ينج گر مر بذر از هر نمونه تيمـارى انتخـاب و

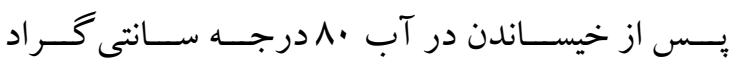
يوست گيرى و آندوسيرم آنها جدا و در آون خشـكانده

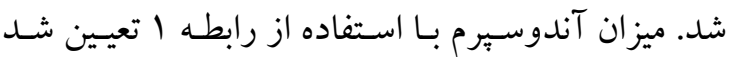
.(El-awad, 1998) (رابطه |) ه/ ( . (1 وززن نمونه آندوسبرم) =ميزان آندوسبرم (درصد) تجزيــه دادههــا و رســـم نمودارهـــا بــا اســفاده از نرمافزارهـاى SAS و OriginPro 9.1، Excel و مقايسـه ميـانگين هـا بـه روش آزمـون حسداقل تفـاوت معنسىدار (LSD)

\section{نتايج و بحث}

نتايج مقايسه ميانگين ها نشان داد كه اثر متقابل تاريخ كاشت و اكوتيّ در تاريخ كاشتهاى مورد بررسى بـر

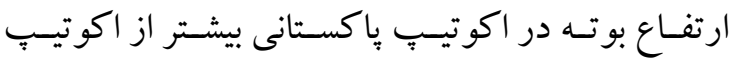
هندى بود (جــدول r). بيشـترين ارتفـاع بوتـه در تـاريخ
كليه فعاليتهاى داشت شامل تنكك كردن و وجين علف هاىهرز، كوددهى و آبيارى به نحو مطلوب انجـام شـد. با توجه به غناى خـاكك مزرعـه از نظـر فسـفر و يتاسـيم، فقط • ها كيلو گرم در هكتار نيتـروزن (از منبـع اوره) در دو نوبت (مرحله جهار بر گى و مرحله طويل شدن ساقه) به صورت نوارى ( · ال سانتيمتر در كنـار و يـنج سـانتيمتر در زير محل كاشت بذر ) در كنار رديفهاى كاشت به خاكك داده شد. آبيارى با استفاده از تيِ و بـا توجـه بـهـ بافت بسيار سبك خاكك مزرعه (جدول () به مقدار كم، در فواصل زمانى نزديككتر انجام شد، به طسورى كـه بـه صورت جشمى علائم تنش كم آبى در كرتها مشاهده نشـود. تعيـين تعـداد روز تـا رسـيدكى در هـر تيمـار،

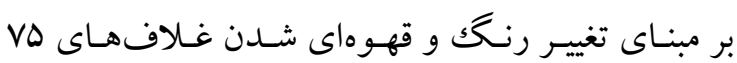
درصد بوتههاى هـر كـرت در نظـر كرفتـه و ثبـت شـد (Gohar Ansari and Aparna, 2017) (در يايـان فصـل رشد، يس از حذف حاشيهها، نمونهبردارى تصـادفى از رديفهاى ميانى كرت ها صورت كرفت ( •ا بوته از هر كــرت آزمايشـى) و ارتفــاع بوتــه، تعسداد غـلاف در مترمربع، عملكرد ماده خشكك، وزن صد دانه، عملكرد دانه، شاخص برداشت و ميـزان آندوسـبرم انـدازه كيـرى شدند. براى اندازه كيرى عملكرد ماده خشك و عملكرد دانه، يس از كفبر كردن بوتههاى هـر كرت از سـطح يكك مترمربع و خشكاندن نمونه ها در آون، عملكرد ماده 
طول دوره رويشى كمتر)، ارتفاع بوته اكوتيّ بِاكستانى

تفـاوت معنسى دارى بـا اكو تيسبِ هنـدى نداشـت، امـا در

تـاريخ كاشـتهـاى مســاعد، ارتفــاع بوتسه در اكوتيستِ

باكستانى بيشتر از اكوتيِ هندى بـود. دكـا و همككاران

در ارزيـابى اثـر تـاريخ كاشـت (Deka et al., 2015)

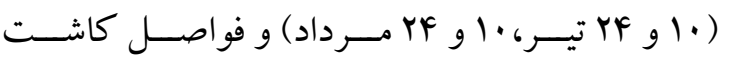

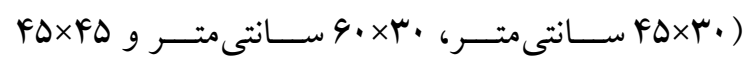

سانتىمتر) بر رشد و عملكرد گوار گزارش دادند كه در

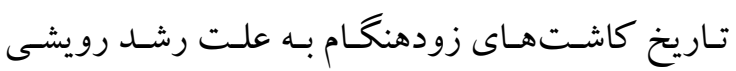$$
\text { مناسب، ارتفاع بوتها بيشتر بود. }
$$

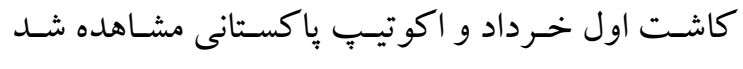

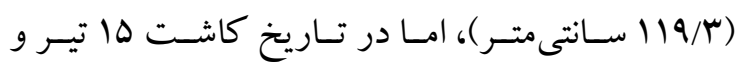
اكوتيبِ هنـدى ارتفـاع بوتهه حسدود •له درصـد كـاهش

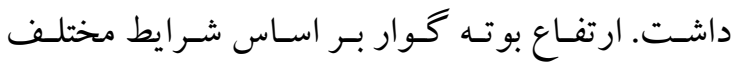
محيطى و مديريتى از ·له تا · .. سانتى متـر متغيـر اسـت.

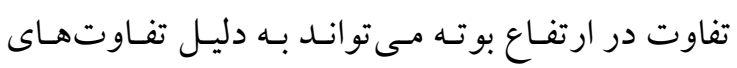
زنتيكى هـر رقـم باشـد (Akhtar et al., 2012). در ايسن آزمـايش در هـر تـاريخ كاشـت، ارتفــاع بوتـهـ كـوار در

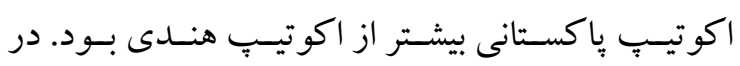

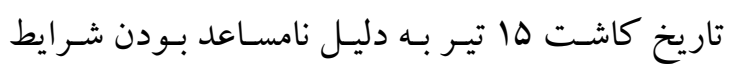
محيطى (ميانكين دمـاى بيشـتر در ابتـداى فصـل رشـد و

جدول ب- مقايسه ميانگين ارتفاع بوته گوار (سانتىمتر) در اثر متقابل تيمارهاى تاريخ كاشت و اكوتيب

Table 3. Mean comparison plant height of guar $(\mathrm{cm})$ in interaction effect of planting date and ecotype treatments

\begin{tabular}{|c|c|c|c|c|c|}
\hline & & 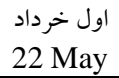 & يانزدهم خرداد 5 June & $\begin{array}{c}\text { اول تير } \\
22 \text { Jun }\end{array}$ & $\begin{array}{l}\text { بانزدهم تير } 6 \text { July } \\
\text { با }\end{array}$ \\
\hline Pakistani ecotype & اكوتيبٍ پِاكستانى & $119.3 \mathrm{a}$ & $108.8 \mathrm{a}$ & $85.4 \mathrm{a}$ & $67.1 \mathrm{a}$ \\
\hline Indian ecotype & اكو تيب هندى & $89.0 \mathrm{~b}$ & $78.6 \mathrm{~b}$ & $69.5 b$ & $58.5 b$ \\
\hline
\end{tabular}

در هر ستون ميانخينهايى كه داراى حروف مشترك هستند، بر اساس آزمون حداقل تفاوت معنى دار در سطح احتمال بنج درصد تفاوت معند

Means in each column followed by similar letter(s) are not significantly different at 5\% probability level, using LSD test

به نظر مىرسد كه در تراكم بوته كمتر، دسترسسى بيشـتر

به منابع و رقابـت كمتـر باعـث ارتفــاع بوتهـ بيشـتر شـــه

باشـد. ساسـميتا و همكـاران (Sasmita et al., 2017) نيـز

كزارش دادند كه ارتفاع بوته گوار با افزايش فاصله بـين

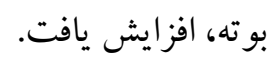

نتايج نشان داد كه تعداد روز از كاشـت تـا برداشـت توات

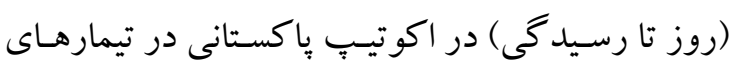

تاريخهاى كاشت بيشتر از اكوتيب هندى بود (شكل بل ب).
نتايج مقايسه ميانگين ها نشان داد كه بيشترين ارتفـاع بوته از تراكم ·سا هزار بوته در هكتار و كمترين ارتفاع

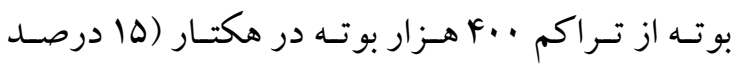
كاهش) بدست آمـد (جـدول \&). واضـح اسـت كـه در تراكم بوته كم، رقابت بين كونهاى كمتر بوده و كياهان

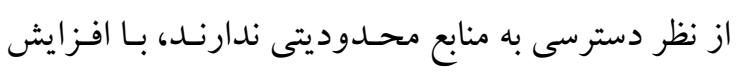

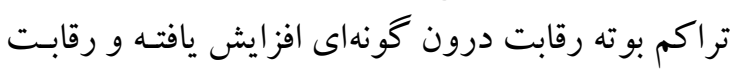
بوته ها براى دسترسى به منابع افزايش مسى يابسـ. بنـابراين

جدول F- مقايسه ميانگين ارتفاع بوته، تعداد روز تا رسيدكى و شاخص برداشت اكوتيٍ هاى گوار در تيمار تراكم بوته

Table 4. Mean copmarisons of plan height, days to maturity and harvest index in guar ecotypes in plant density treatment

\begin{tabular}{|c|c|c|c|}
\hline $\begin{array}{c}\text { تراكم بوته } \\
\text { Plant density (plant.ha-1) }\end{array}$ & $\begin{array}{c}\text { روز تا رسيدگى } \\
\text { Days to maturity }\end{array}$ & $\begin{array}{c}\text { ارتفاع بوته } \\
\text { Plant height (cm) }\end{array}$ & $\begin{array}{c}\text { شاخص برداشت } \\
\text { Harvest index (\%) }\end{array}$ \\
\hline 130000 & $100.6 \mathrm{c}$ & $91.6 \mathrm{a}$ & $21 \mathrm{a}$ \\
\hline 200000 & $102.6 \mathrm{~b}$ & $84.2 b$ & $19 \mathrm{ab}$ \\
\hline 400000 & $105.2 \mathrm{a}$ & $77.9 \mathrm{c}$ & $16 b$ \\
\hline
\end{tabular}

در هر ستون ميانگينهايى داراى حروف مشترك هستند، بر اساس آزمون حداقل تفاوت معنىدار در سطح احتمال بنج درصد تفاوت معنىدارى ندارند

Means in each column followed by similar letter(s) are not significantly different at 5\% probability level, using LSD test 
رشد در تـاريخ كاشت اول خـرداد در هـر دو اكوتيـبِ

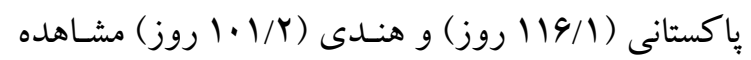
شد و كمترين طول دوره رشد در تاريخ كاشـت ها تيـر

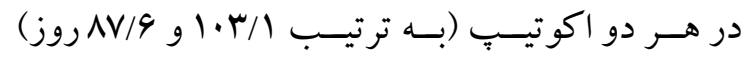

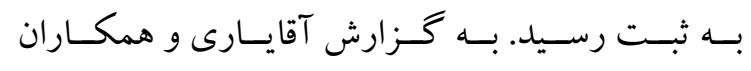
يـك رابطه ر خرسيونى منفى (Aghayari et al., 2016) بين تاخير در كاشت سـويا و طـول دوره رشـد كيـاه (از

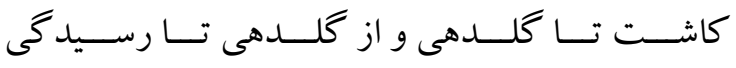
فيزيولوزيكك) وجود داشت و با تاخير در كاشـت، طـول دوره رويشى و زايشى سويا كاهش يافت.

$$
\begin{aligned}
& \text { بيشترين طول فصل رشـد در اكوتيـبِ پاكستانى كشـت } \\
& \text { شده در تاريخ اول خـرداد مشـاهده شــ (19/1 ا روز) و } \\
& \text { طــول فصـل رشــــ در تــاريخ كاشـت يــانز دهم تيــر }
\end{aligned}
$$

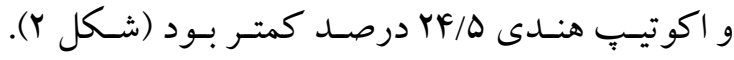

$$
\begin{aligned}
& \text { بر اين اساس مى توان نتيجه كرفت كه اكوتيٍّ پاكستانى }
\end{aligned}
$$

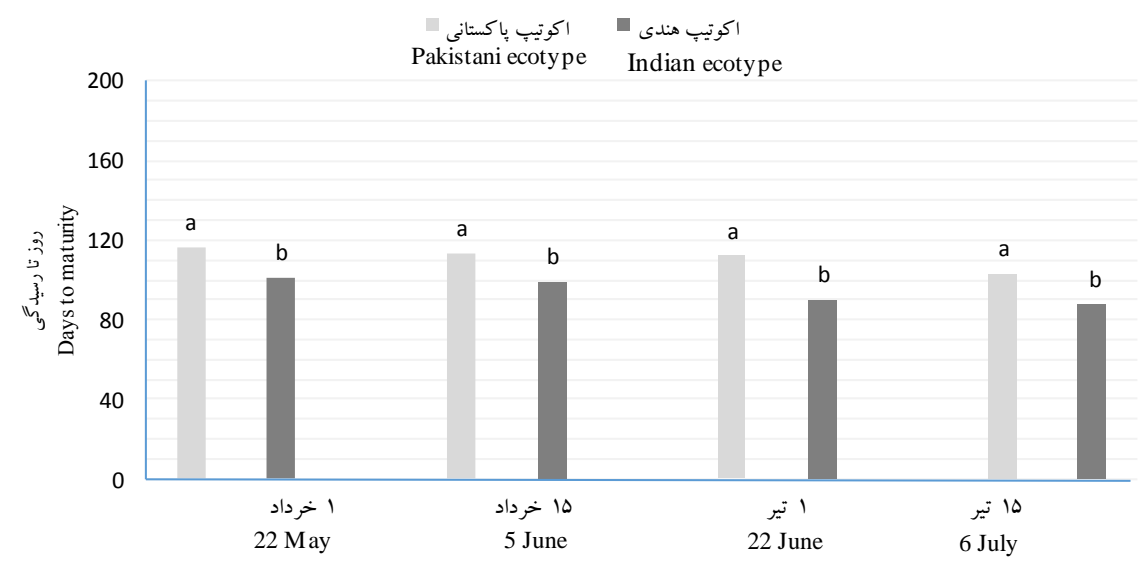

شكل r- مقايسه ميانكين تعداد روز تا رسيدكى اكوتيبه هاى گوار در اثر متقابل تيمارهاى تاريخ كاشت و اكوتيب

Fig. 2. Mean comparison of days to maturity of guar ecotypes in interaction effect of planting date and ecotype treatments

طول فصل رشد ذرت در تراكمهـاى بـالا در مقايسـه بـا تراكمهاى يايين كمتر بود. نتايج نشان داد كه تعداد غلاف در مترمربـع فقط در تـاريخ كاشـت اول خـــداد در بـين تـراكمهـــ مـورد ارزيـــابى تفـــاوت معنـــى دارى داشـــت (شـــكل ب).

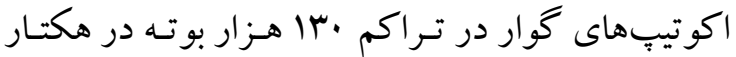
بيشترين تعداد غلاف در متر مربـع را داشـتند. در تـاريخ كاشت زود هنگكام با توجـه بـه مسـاعد بـودن شـرايط در دوره رشد زايشى (روزهاى بلندتر، گرم و رطوبت كم)،

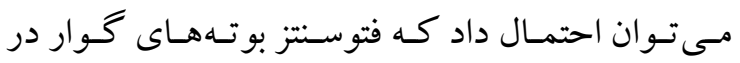

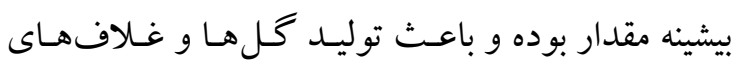
بيشـرى شــده باشـد، امـا در تـاريخ كاشـت هــاى دير تـر

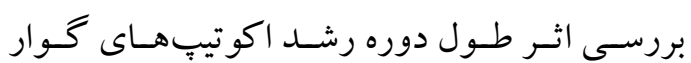
در تيمارهاى تراكم بوتـه، رابطهاى مثبـت و معنى دارى را نشان داد (جـدول F). بيشـترين و كمتـرين تعـداد روز

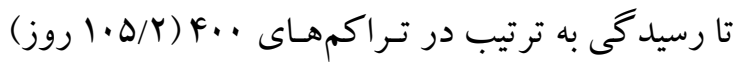
و ·سا هزار بوته در هكتـار (9/4. · اروز) مشـاهده شـد. انتظـار مسىرفـت كــه در تـــراكمهــاى بوتـهـ بــالا، بـهـ دليل افزايش رقابت براى مواد غذايى و منـابع محيطى، بوتهاى كوار زودتر به يايـان مرحله رسـيدكى برسـند،

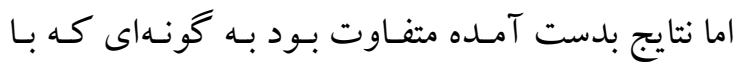
افـز ايش تـر اكم بوتـه، طـول دوره رشـــ افزايش يافـت.

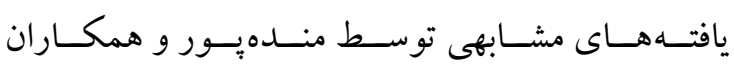
كـزارش شـده اسـت كـه (Mendehpour et al., 2014) 
در تاريخ كاشت اول خرداد با افزايش تـراكم بوته، تعداد غلاف در مترمربع كاهش يافت. به نظر مسىرسـد

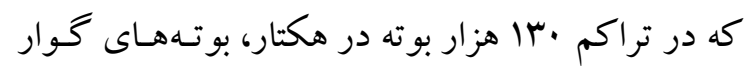
با دسترسى به منابع مورد نياز محيطى در مرحله رويشى و زايشى تعداد بيشترى غلاف در مترمربع توليد كردنـد.

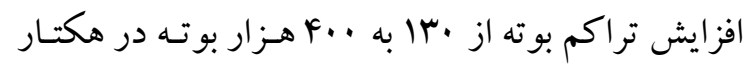

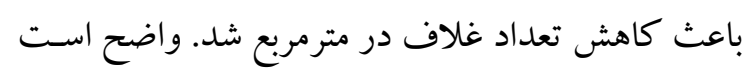
كـه افززايش تـراكم بوتـه باعـث كـاهش تعـداد غـلاف

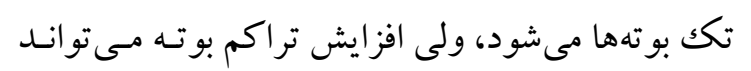
كاهش تعداد غلاف تكك بوته را جبران كند، اما ايسن در

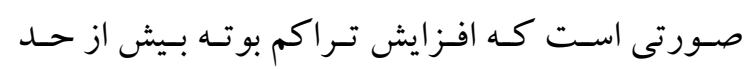

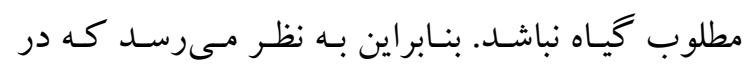

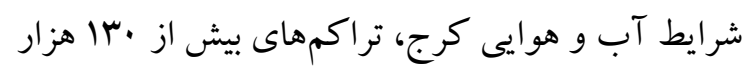

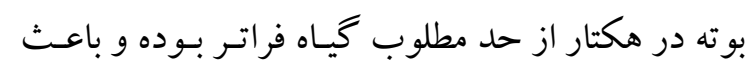

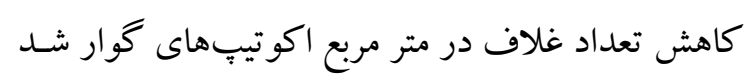

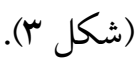

(ها خرداد، اول و ها تير) مرحله زايشى گياه به مرور با شرايط نامساعد محيطى (روزهاى كوتاه، هواى خنككتر و رطوبت بيشتر) مصادف شده و احتمالا فتوسنتز بو تههـا

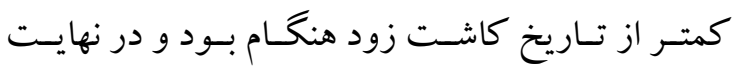

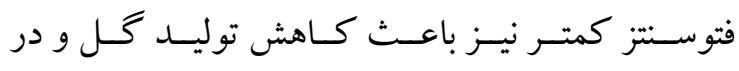
نتيجـه غـلاف در كيـاه شـــ نتـايج آزمـايش رحمـانى و همكـاران (Rahmani et al., 2013 نشـان داد كـه تـاخير در كاشت باعث كاهش توليـد خل و غـلاف و ريـزش غلاف هاى ارقام لوبيـا شـد. آنهـا كز ارش كردنـد كـهـ توليد غـلاف كمتـر در كشـتهـاى ديرهنگـام بـه دليـل ريزش كل ها و ساير عوامل متاثر از دمـاى بـالا در زمـان كلدهى بـوده اسـت. نتـايج آزمـايش لاكشـمى كاليـانى نيز با يافتـهــاى ايـن تحقيـق (Lakshmi Kalyani, 2012) مطابقت داشت. آنها علت بيشتر بودن تعداد غلافهاى

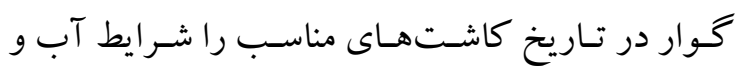
هو ايى مطلوب در طول دوره رشد كياه اعلام كردند.

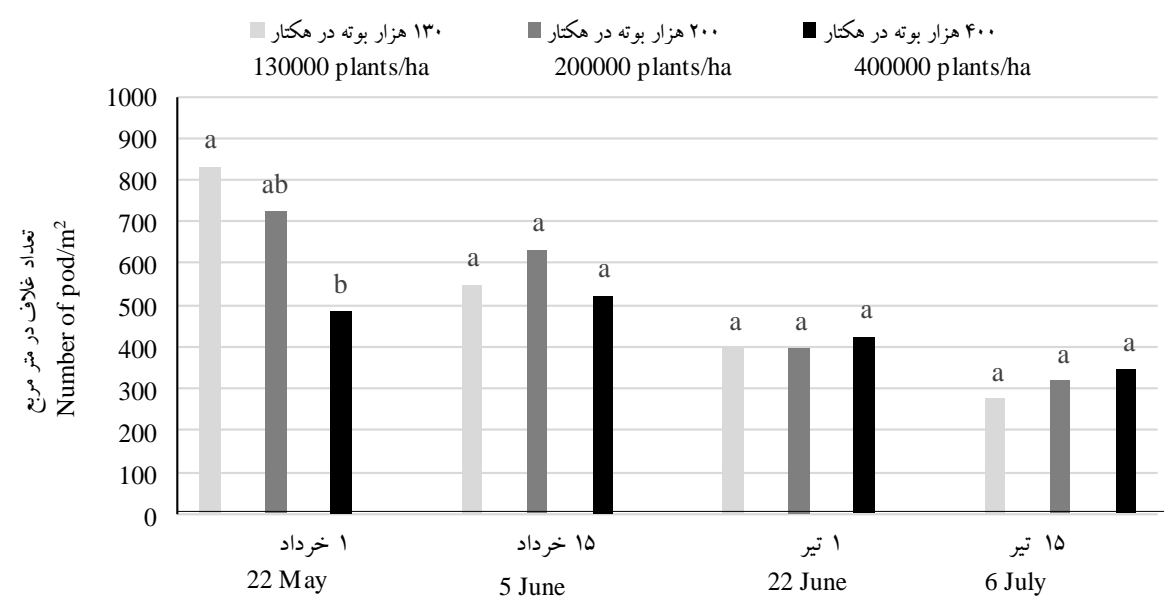

شكل س- مقايسه ميانكين تعداد غلاف در مترمربع اكوتيِهاى كوار در اثر متقابل تيمارهاى تاريخ كاشت و تراكم بوته

Fig. 3. Mean comparison of number of pod. $\mathrm{m}^{-2}$ of guar ecotypes in interaction effect of planting date and plant density treatments

در اكوتيـبٍ ياكسـتانى در مقايسـه بـا اكوتيـبٍ هنـدى

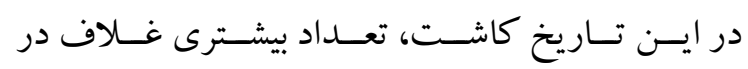

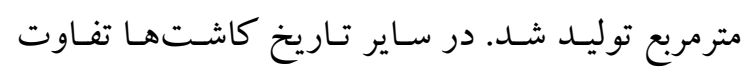

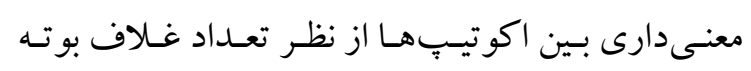

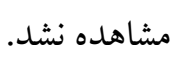

نتـايج بــش دهـى اثـــ متقابـل بــين تـاريخ كاشـت و اكوتيب مشابه نتايج اثر متقايل تاريخ كاشت و تراكم

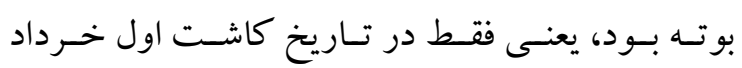

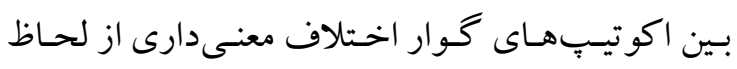
تعـداد غـلاف در مترمربـع وجــود داشـت (شـكل F). 


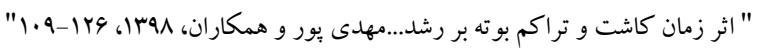

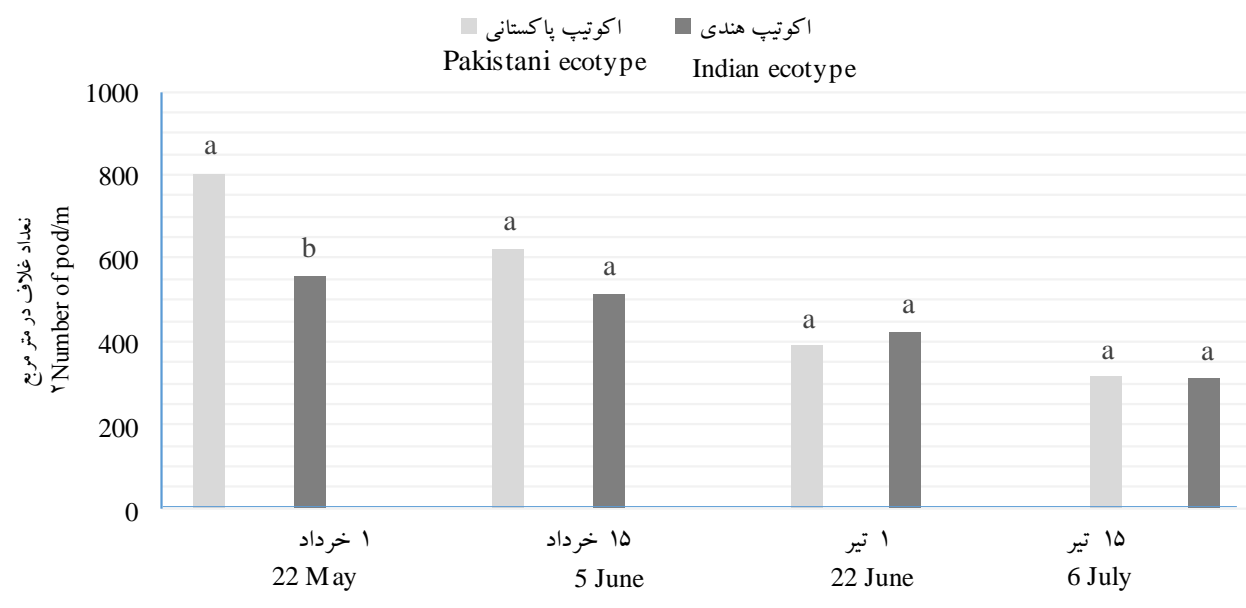

شكل ₹- مقايسه ميانگين تعداد غلاف در مترمربع اكوتيبهاى گُوار در اثر متقابل تيمارهاى تاريخ كاشت و اكوتيب

Fig. 4. Mean comparison of number of pod. $\mathrm{m}^{-2}$ of guar ecotypes in interaction effect of planting date and ecotype treatments

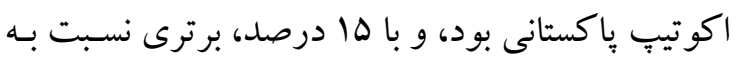

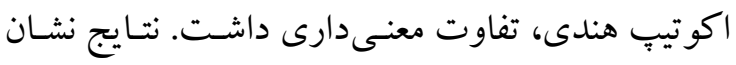
داد كه با تاخير در كاشت وزن هزار دانه كـاهش يافتـ.

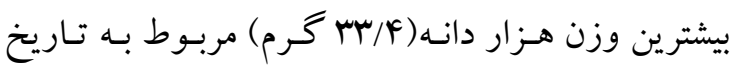

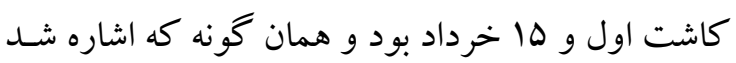
وزن هزار دانه در تاريخ كاشت اول و ها ها تير بـهـ ترتيسب

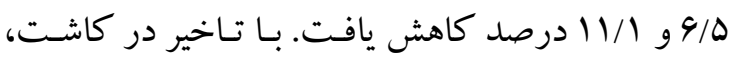

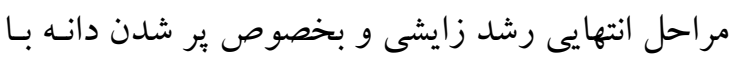

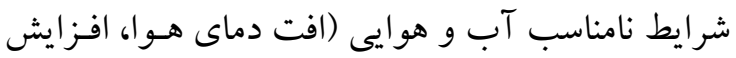
رطوبت هوا و كاهش طول روز) مواجه شده و در نتيجه

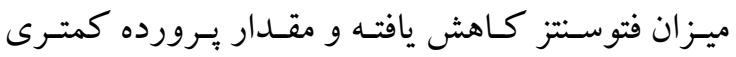
توليد و به دانهها منتقل مىشود. تاخير در كاشـت باعـث كاهش طول دوره رويشى نيـز شـــ و بـه تبـع آن ميـزان

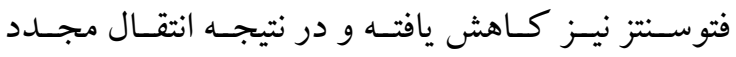
فر آوردههاى فتوسنتزى به دانهها نتوانست كو تاهى فصل ئل فئل

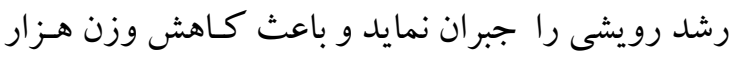

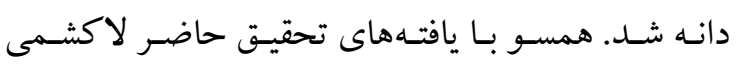

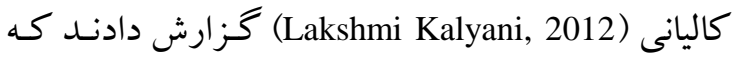
در تاريخ كاشتهاى زودتر در ارقام گوار، وزن دانه بـهـ

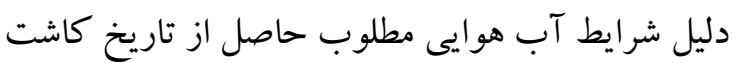
مناسب، بيشتر از تاريخ كاشتهاى دير هنكام بود.
بــا توجسه بـهـ اينكـه در تـاريخ كاشـت اول بـين دو

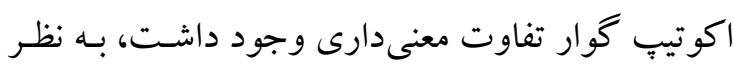

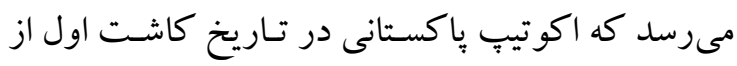

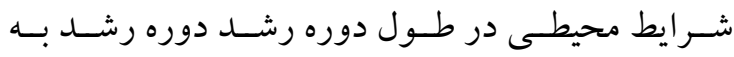

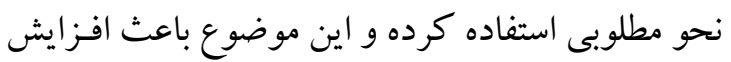

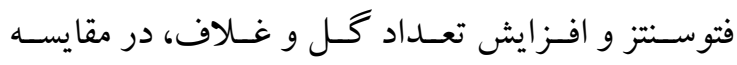

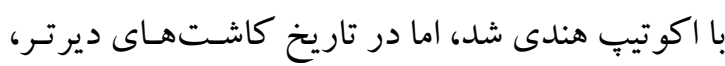

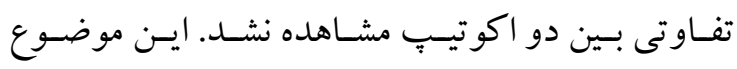

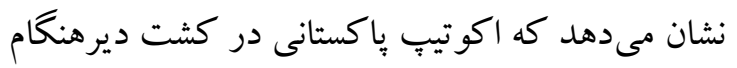

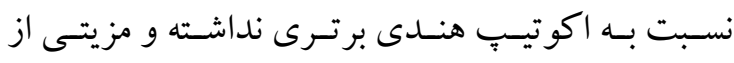
نظــر اسـتفاده از منـابع محيطى نداشــت نتسايج سـاير تحقيقات نيز نشان داده است كه تاريخ كاشت بـر تعسداد

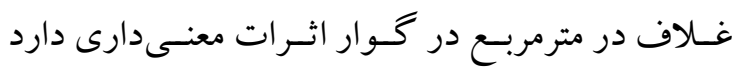
.(Taneja et al., 1995; Bhadoria and Chauhan, 1994) اثر تاريخ كاشت و اكوتيب بر وزن هزار دانـه گـوار

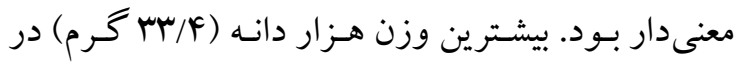

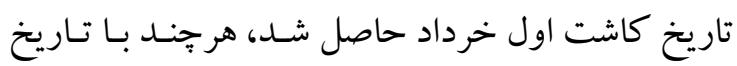

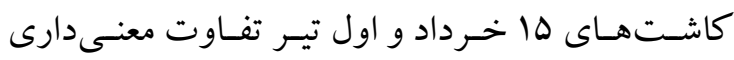

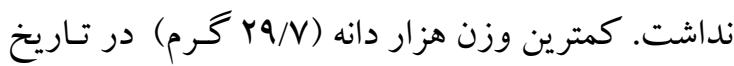

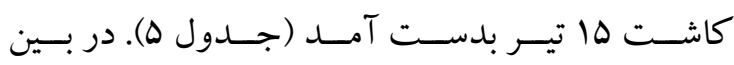

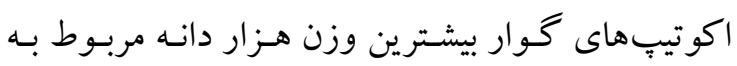




$$
\text { "نشريه علوم زراعى ايران"، جلد بيست و يكم، شماره r، تابستان 1هبا }
$$

جدول ه- مقايسه ميانكين وزن هز ار دانه و شاخص برداشت اكوتيٍٍ هاى گوار در تيمارهاى تاريخ كاشت وتراكم بوته

Table 5. Mean comparisons of 1000 seed weight and harvest index of guar ecotypes in planting

\begin{tabular}{|c|c|c|c|c|}
\hline $\begin{array}{c}\text { تاريخ كاشت } \\
\text { Planting date }\end{array}$ & \multirow[t]{2}{*}{$\begin{array}{c}\text { تراكم بوته } \\
\text { Plant density } \\
\text { (plant ha-1) }\end{array}$} & \multirow[t]{2}{*}{ اكوتيِّهاى گوار } & \multirow{2}{*}{ 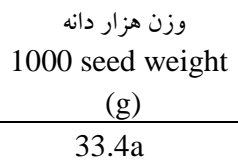 } & \multirow{2}{*}{$\begin{array}{c}\begin{array}{c}\text { Endosperm content } \\
\text { (\%) }\end{array} \\
40.4 a\end{array}$} \\
\hline 22 May اول خرداد & & & & \\
\hline ها خرداد & & & $33.4 \mathrm{a}$ & $39.8 \mathrm{a}$ \\
\hline 22 June & & & $31.2 \mathrm{ab}$ & $39.3 \mathrm{a}$ \\
\hline \multirow[t]{6}{*}{6 July } & & & $29.7 \mathrm{~b}$ & $39.2 \mathrm{a}$ \\
\hline & 130000 & & $32.2 \mathrm{a}$ & $39.9 \mathrm{a}$ \\
\hline & 200000 & & $32.5 \mathrm{a}$ & $39.6 \mathrm{a}$ \\
\hline & 400000 & & $31.1 \mathrm{a}$ & $39.5 \mathrm{a}$ \\
\hline & & Pakistan باكستانى & $34.5 \mathrm{a}$ & $40.5 \mathrm{a}$ \\
\hline & & Indian هندى & $29.4 b$ & $38.8 \mathrm{~b}$ \\
\hline
\end{tabular}

در هر ستون ميانگينهايى كه داراى حروف مشتر كك هستند، بر اساس آزمون حداقل تفاوت معنى دار در سطح احتمال ينج درصد تفاوت معنى دارى ندارند

Means in each column followed by similar letter(s) are not significantly different at 5\% probability level, using LSD test

از مطلوبيت كشت كوار با تراكم ·ـا هزار بوتـه كاسته

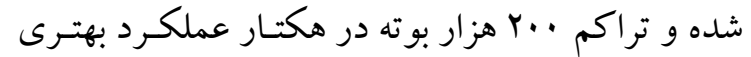

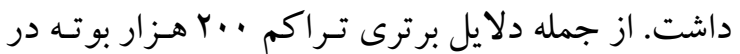

هكتار مى توان به اين موضوع اشاره كرده كـه تـاخير در

كاشت باعث افت عملكـرد دانسه كـوار شـد، امـا تـراكم

r...

طريق تعداد غـلاف در بوتـه (شكل ب) و مـاده خشك بك له

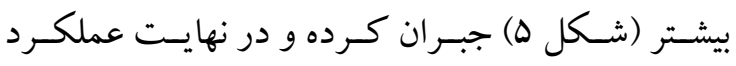

بالاترى در مقايسه با تر اكمهاى ديخر به دست آمد.
بين تراكمهاى بوته در تاريخ كاشـتهـاى اول و ها خرداد از نظـر عملكـرد دانسه تفـاوت معنسىدارى وجـود داشت، بهطورى كـه بـا تـاخير در كاشـت عملكـرد دانـه كوار اكو تيٍّاى كاهش يافت. بيشينه عملكرد دانسه در

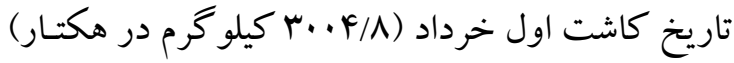
در تراكم • سا هزار بوته در هكتار به دست آمد، امـا در تاريخ كاشت ها خـرداد بيشـينه عملكـرد بـا هب درصــ

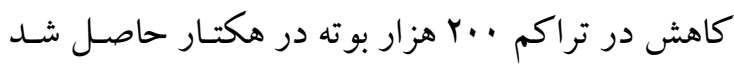
(شكل ه). به عبارت ديكر در تاريخ كاشت ها خـرداد

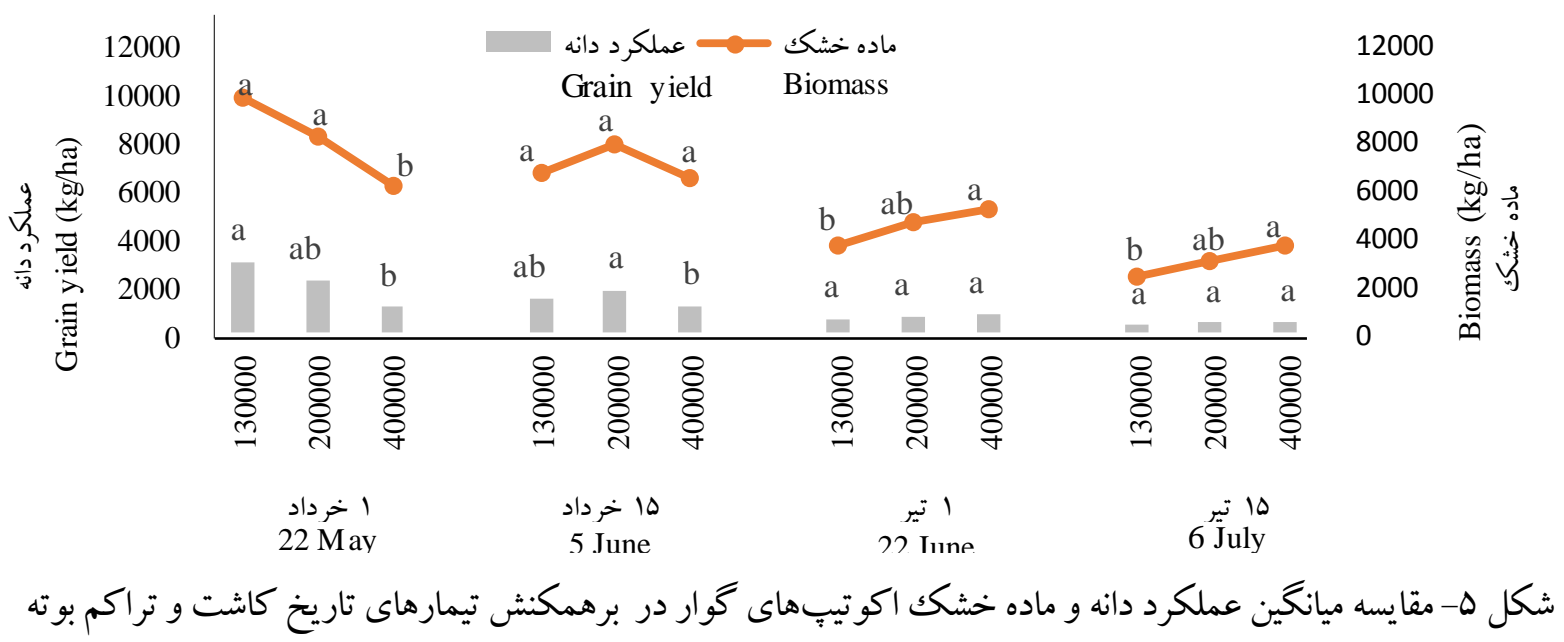

Fig. 5. Mean comparison of seed yeild and biomass of guar ecotypes in interaction effect of planting date and plant density treatments 
عملكـرد دانـه بيشـترى راد داشـت. قابـل ذكـر اسـت كـه

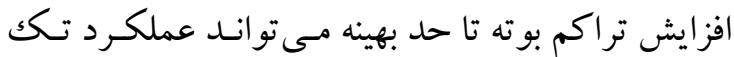

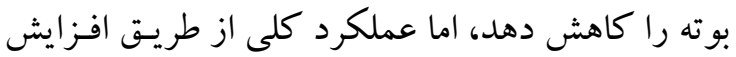

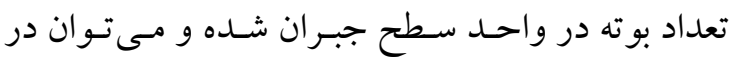
تراكمهاى بالاتر عملكرد دانه بيشترى را بـه دسـت آورد ودرد

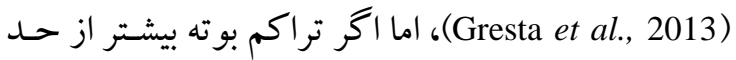

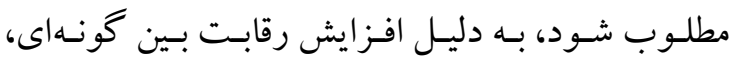

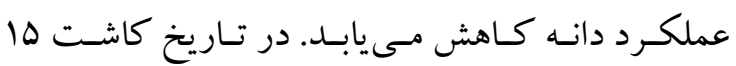

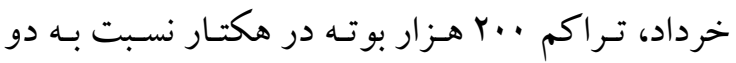

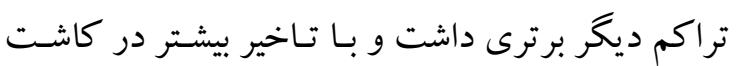

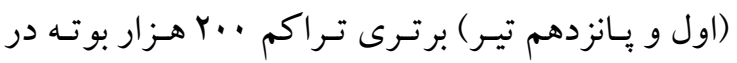

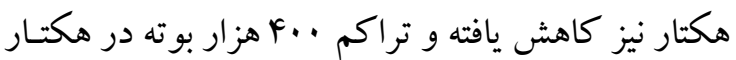

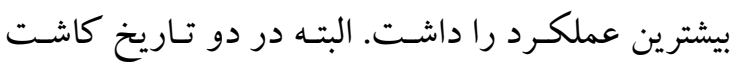

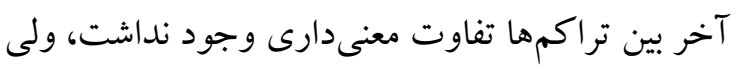

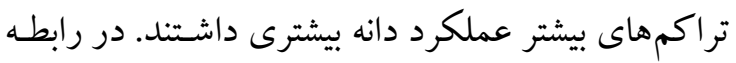

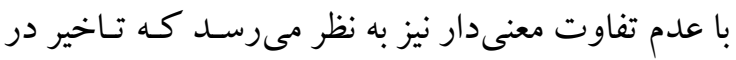

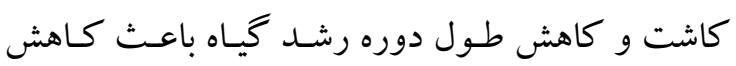
عملكرد كلى (تكك بوته و كل) شده و افزايش بو تـه در درو

واحد سطح نيز باعث جبران اين كاهش عملكرد نشد. نتايج برشدهى اثر متقابل تـاريخ كاشـت و اكوتيـبِ

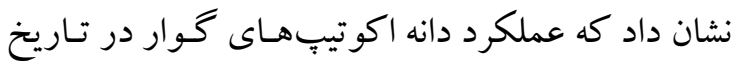
كاشـت اول و ها خـــداد تفــاوت معنسىدارى داشـت

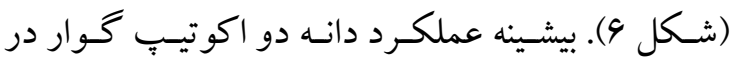

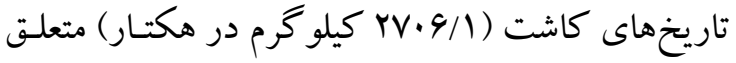
به اكوتيب پاكستانى در تاريخ كاشـت اول خـرداد بـود،

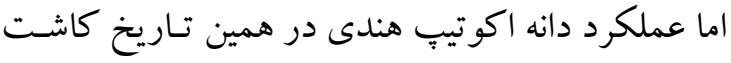

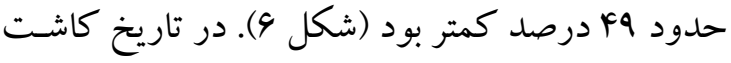

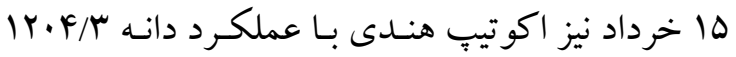

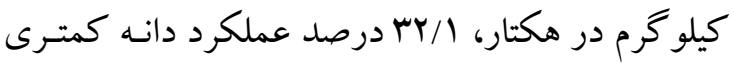

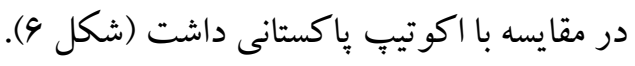

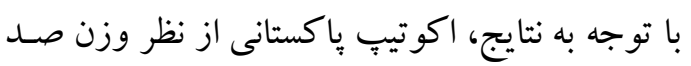

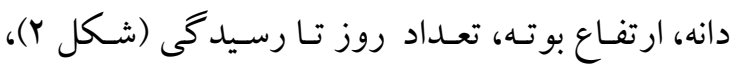

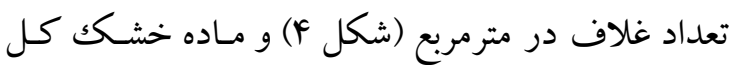

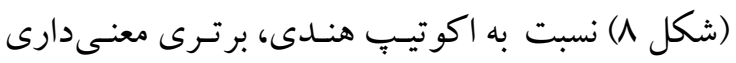

به نظر مىرسد كه كاهش دما در اواخر فصل رشـد، نقش مهمس در كـاهش عملكـرد دانسه داشـته اسـت. بـر اساس اطلاعات شكل ا، در انتهاى فصل رشـــ ميـانگين

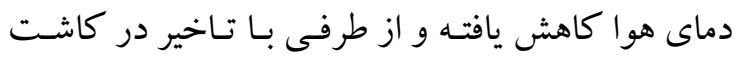
(كشت در تاريخ ها خرداد در مقايسه بـا اول خـرداد)،

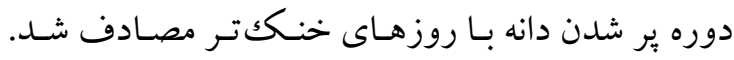

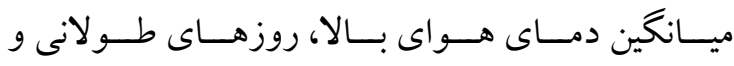

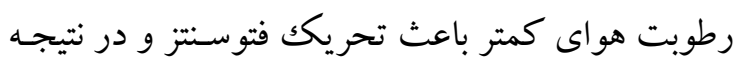

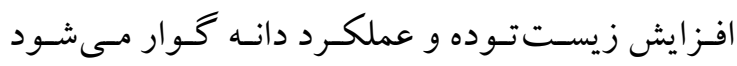

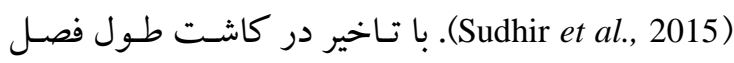

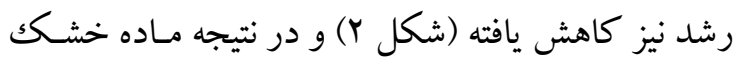
تجمعى در طول فصل كمتر شده و عملكرد دانه كمترى به دست مى آيد (Singla et al., 2016). با توجه به اينكـه تاريخ كاشت بر عملكـرد دانه و طول دوره رشــ كيـاه

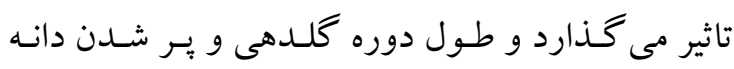

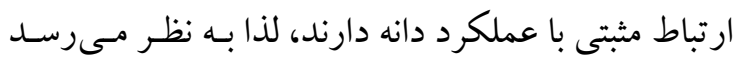

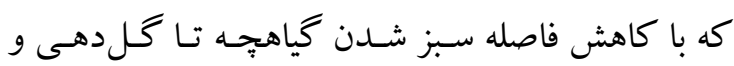

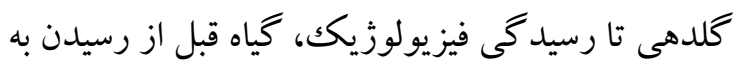

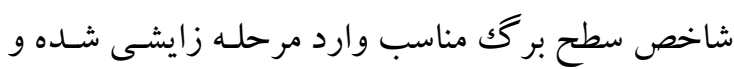

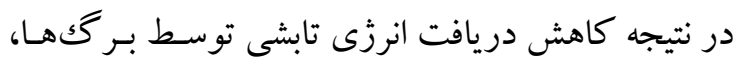

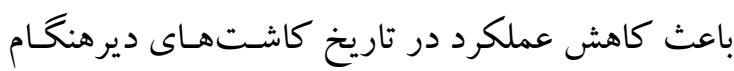
مسىشـود (Khademhamzeh et al., 2004). سـينگكلا

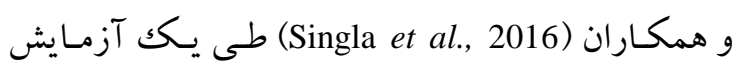

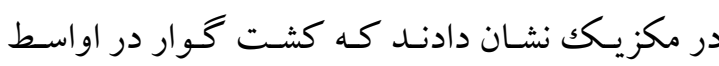

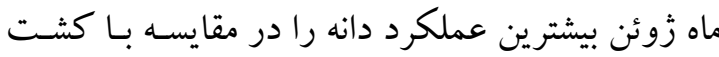

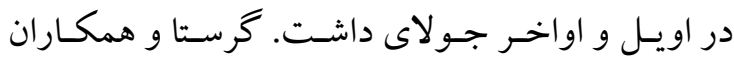
نيز طى يـك آزمايش در ايتاليـا (Gresta et al., 2013) نشان دادند كه كشت گوار در تاريخ كاشتهاى زودتر لتر باعث افزايش عملكرد دانه شد. در تاريخ كاشت اول خرداد بيشترين عملكـرد دانه دئه در تراكم • با هزار بوته در هكتـار بـه دسـت آمــد و بــا افزايش تراكم بوته، عملكرد دانه كاهش نشـان داد. ايسن

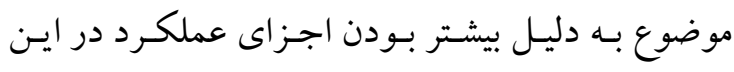

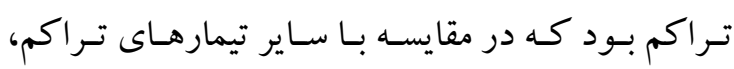




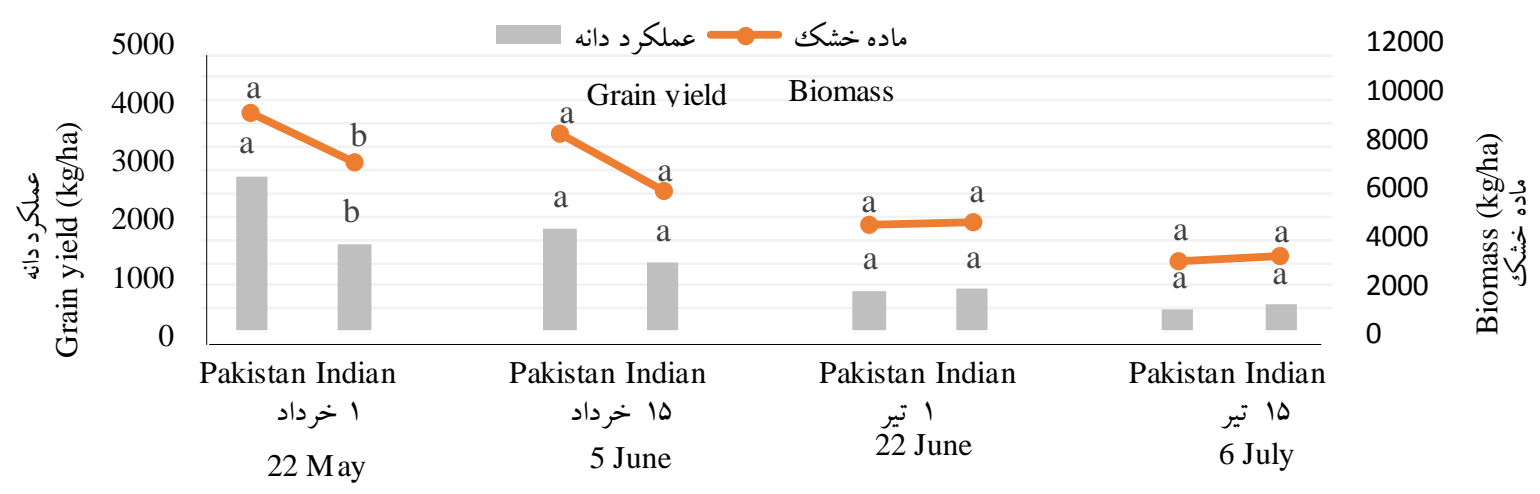

شكل 9- مقايسه ميانكين عملكرد دانه و ماده خشك اكو تيبهاى گوار در برهمكنش تيمارهاى تاريخ كاشت و اكوتيب

Fig. 6. Mean comparison of seed yield and biomass of guar ecotypes in interaction effect of planting date and ecotype treatments

كلدهى و تعداد روز تـا رسيدگ

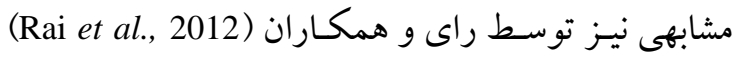
كز ارش شده است. نتايج نشان داد كه اثر تـاريخ كاشـت، تـراكم بوتهه، اكوتيبِ و اثر متقابل تاريخ كاشت در تراكم بوتهـ و اثر

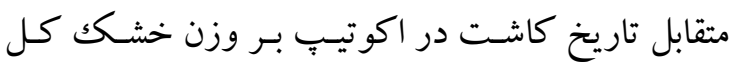

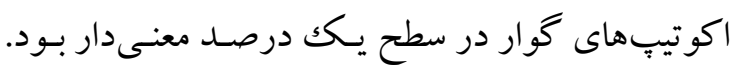

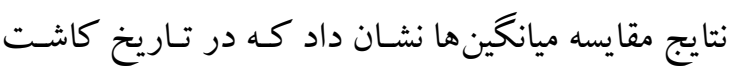

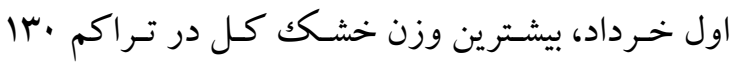

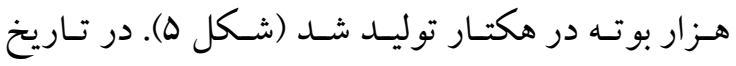

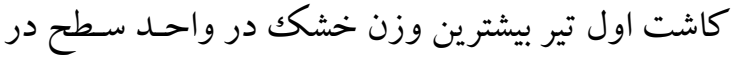

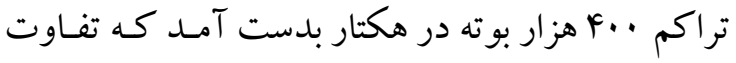

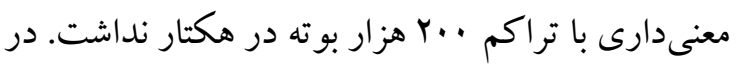

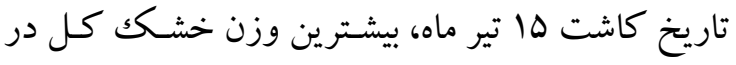

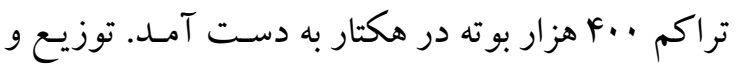

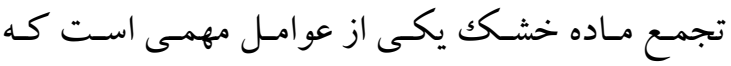

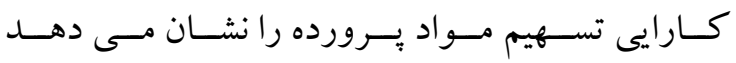
(Satyavathi and Vanaja, 2017) كل با تاخير در كاشت در كليه تراكمهـا را مسىتـوان بـهـ

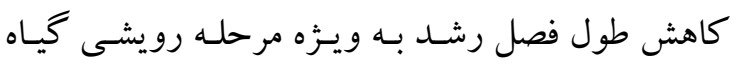

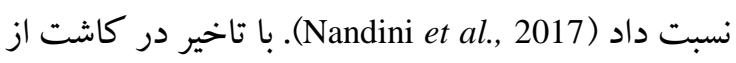
طول دوره رويشى گياه و دوره فتوسنتز فعال گياه كاسته
داشته و باعث عملكرد دانه بيشتر در ايسن اكوتيـبِ شـد.

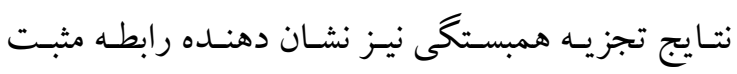

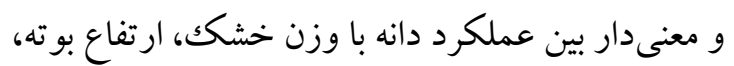

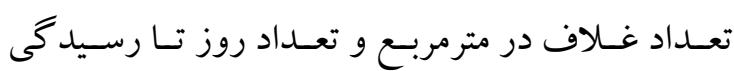

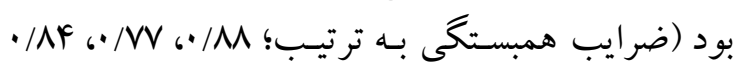

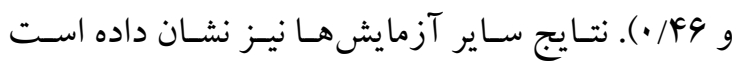

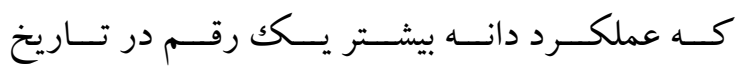

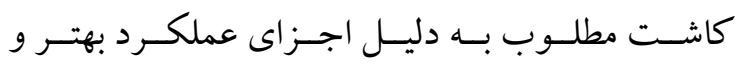

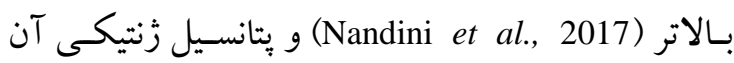

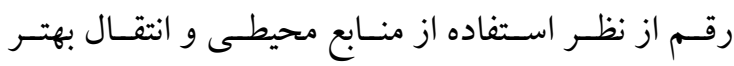

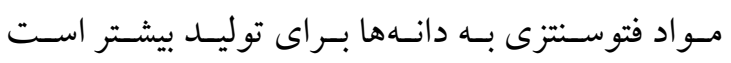
(Lakshmi Kalyani, 2012) تاريخ كاشتهاى ديرهنگام به دليل كاهش فتوسـنتزى و

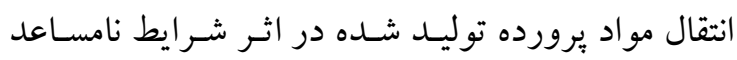

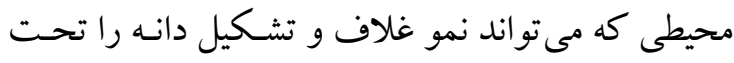

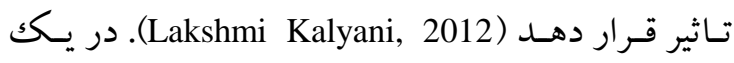

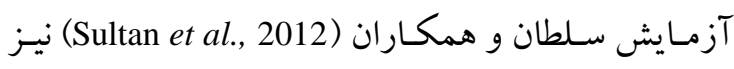

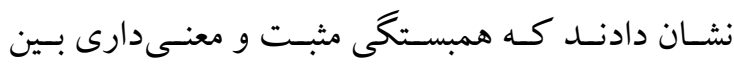
عملكـرد دانـه و تعـداد شـاخه و خوشـه در بوتـه، تعـداد غلاف در خوشه و تعـداد غـلاف در بوتـه گـوار وجـود

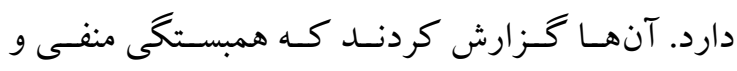

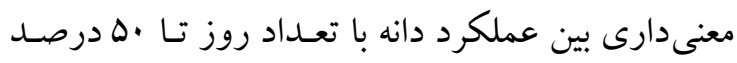


برداشـت را دارا بـود (جــدول F). در تراكمهـاى بـالا،

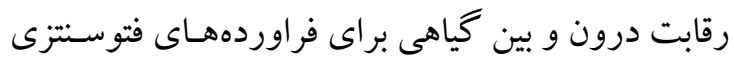
تشديد مىشود و از آنجا كه جوانسهـاى زايشى بعـــ از

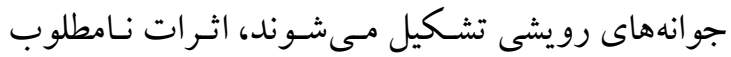

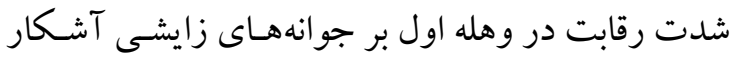

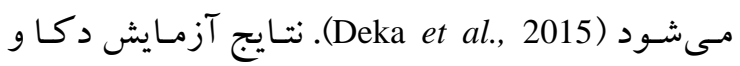
همكاران (Deka et al., 2015) نشـان داد كـه شـاخص إنس

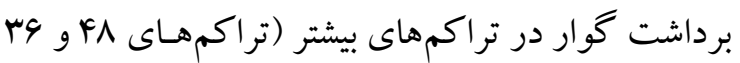

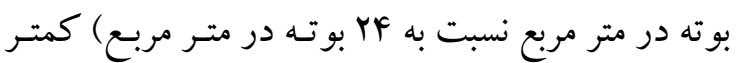

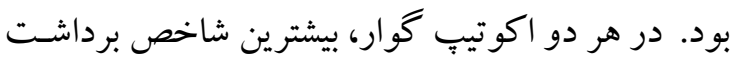
در تساريخ كاشـت اول خــرداد مشــاهده شـــ و تساريخ كاشت ها تير كمترين مقدار شاخص برداشت را داشت

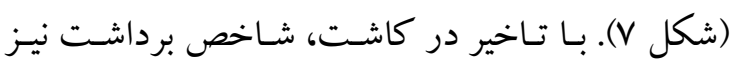
كاهش داشت. كاهش در شاخص برداشت مى توانـلـ بـهـ

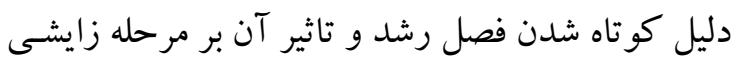

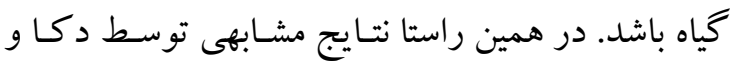

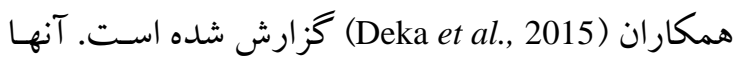

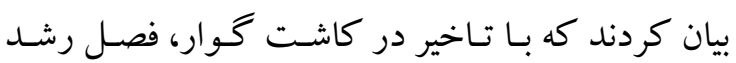

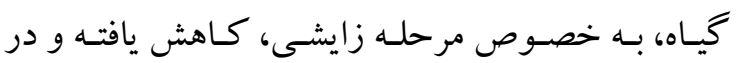
نهايت باعث كاهش تعداد كل و غلاف در بوتـه شـده و عملكرد دانه كاهش يافت.
شده و در نتيجه مـاده خشكك كمترى در گيـاه تجمـع

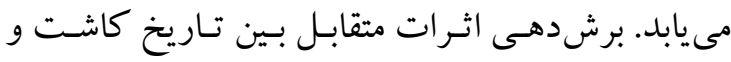

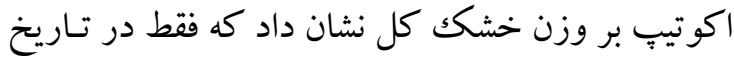
كاشتهاى خـرداد (اول و ها خـرداد) بين اكوتيسبهـا

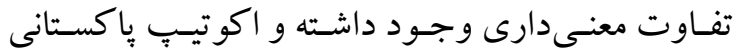

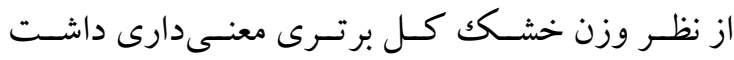

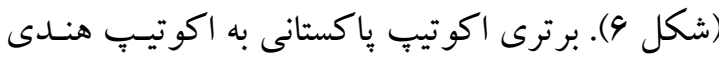
از نظر وزن خشك كل در دو تـاريخ كاشـت اول و 10

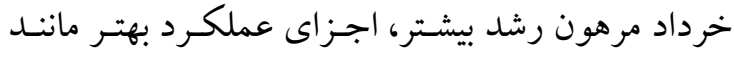

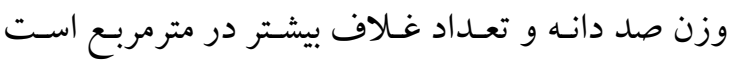
(شكل f). بررسى اثر تاريخ كاشت در سـويا نيـز نشـان

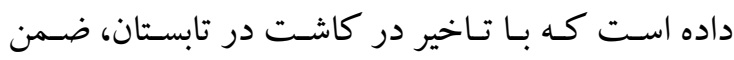

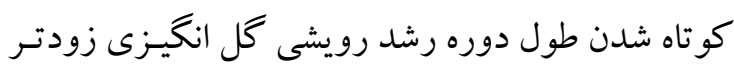

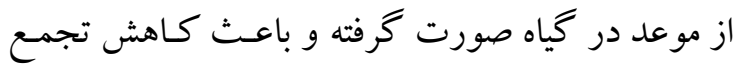
ماده خشك مى شود (Lopez-Bellido et al., 2008). اثر تراكم بوته و اثر متقابل تاريخ كاشت و اكوتيسبِ بر شاخص برداشت اكو تيّهاى كوار معنى دار بـود، بـهـ

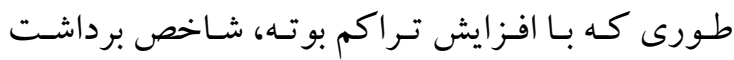
كاهش بيدا كرد. بيشـترين مقـدار شـاخص برداشـت در

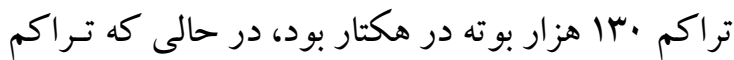
F...

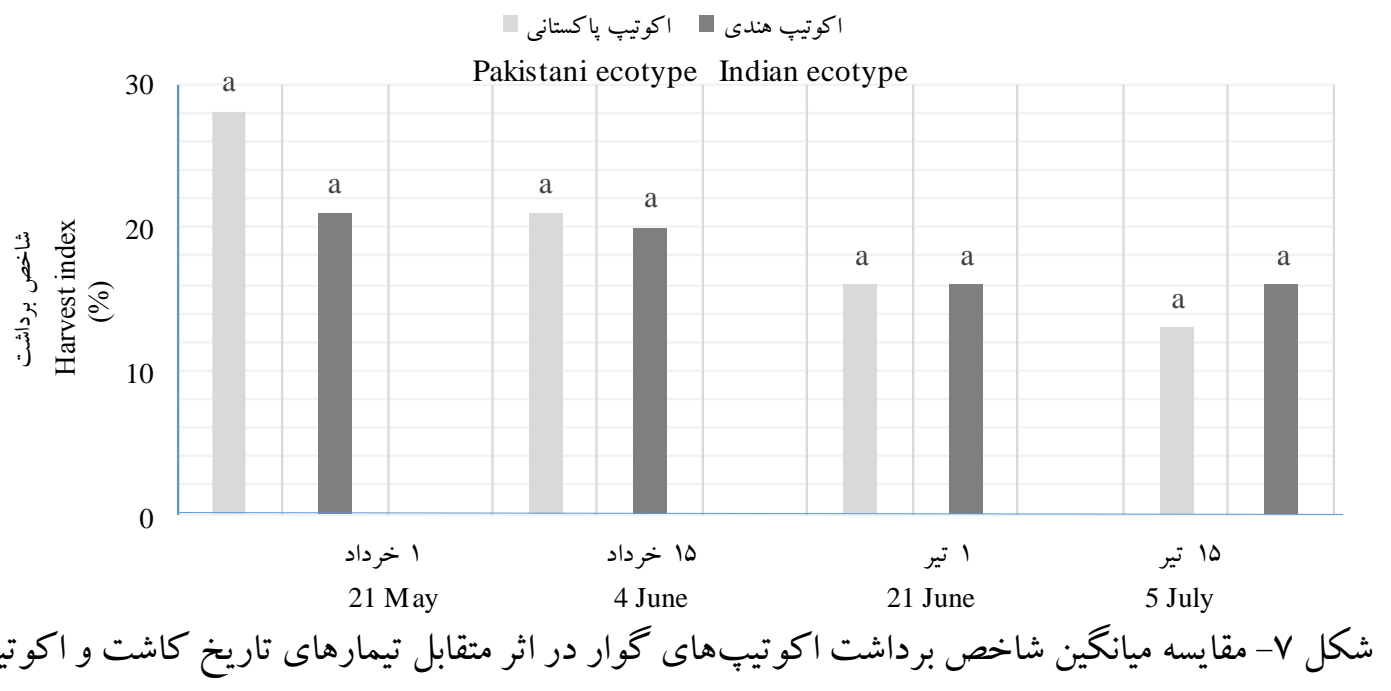

Fig. 7. Mean comparison of harvest index of guar ecotypes in interaction effect on planting date and ecotype treatments 


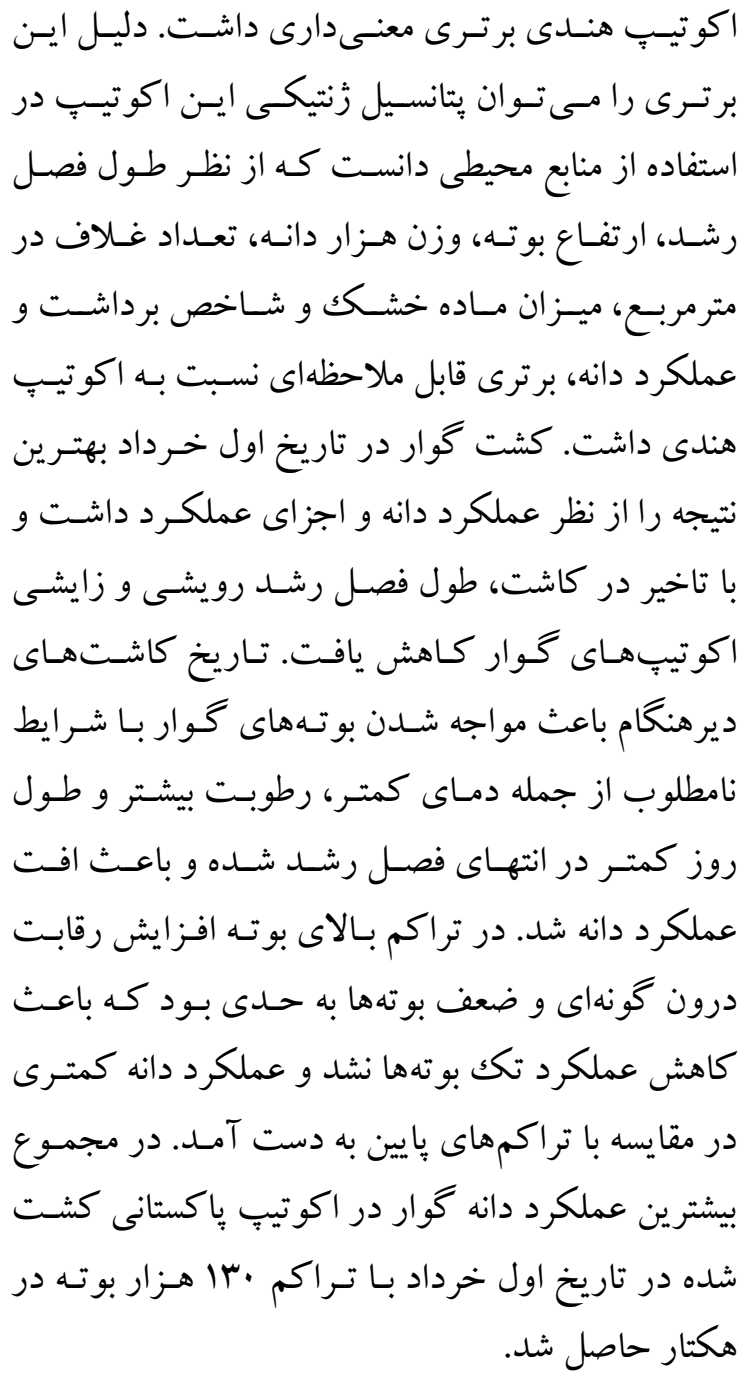

\section{References}

Aghayari, F., A. Faraji and A. Kordkatooli. 2016. Determination of yield and yield components response of soybean (Glycine $\max$ L.) to swing date, temperature and sunshine hours. J. Agroecol. 7(4): 547-562. (In Persian with English abstract).

Akhtar, L. H., S. Bukhari, S. Salah-ud-Din and R. Minhas. 2012. Response of new guar strains to various row spacings. Pak. J. Agric. Sci. 49(4): 469-471.

Akhtar, L. H., R. Minhas, M. S. Bukhari and S. A. Sajid Shah. 2015. Genetic analysis of some quantitative traits of cluster bean (Cyamopsis tetragonoloba L.). J. Environ. Agric. Sci. 4: 48-51.

Ashraf, M. Y., K. Akhtar, G. Sarwar and M. Ashraf. 2002. Evaluation of arid and semi-arid ecotypes of guar (Cyamopsis tetragonoloba $\mathrm{L}$.) for salinity $(\mathrm{NaCl})$ tolerance. J. Arid Environ. 52: 473-482.

Bhadoria, R. B. S. and V. S. Chauhan. 1994. Response of cluster bean (Cyamopsis tetragonoloba L.) to dates of sowing and spacing. Indian J. Agron. 39:156-157.

Deka, K. K., R. Das Milu, P. Bora and N. Mazumder. 2015. Effect of sowing dates and spacing on growth 
" اثر زمان كاشت و تراكم بوته بر رشد...مهدى يور و همكاران،

and cluster bean (Cyamopsis tetragonoloba) in subtropical climate of Assam. Indian J. Agric. Res. 49 (3): 250-254.

El-awad, G. A. 1998. Study of guar seed and guar gum properties (Cyamopsis tetragonolabous). A thesis submitted for the Degree of Master of Science in Department of Food of Science and Technology Faculty of Agricuture University of Khartoum, India.137 P.

Eldirany, A. A., A. A. Mohamed-Nour, K. E. Khadir, K. A. Gadeen and M. Ibrahim. 2015. Physicochemical and Functional properties of four new genotypes of guar (Cyamopsis tetregonoloba L.) gum. Am. J. Food Sci. Health. 1(2): 43-50.

Falasca, S. L., C. Miranda and S. Pitta-Alvarez. 2015. Modeling an agroclimatic zoning methodology to determine the potential growing areas of Cyamopsis tetragonoloba (cluster bean) in Argentina. J. Agric. Sci. 3: $23-39$.

Gendy, A. S. H., H. A. H. Said-Ahl, A. A. Mahmoud and H. F. Y. Mohamed. 2013. Effect of nitrogen sources, bio-fertilizers and their interaction on the growth, seed yield and chemical composition of guar plants. Life Sci. J. 10(3): 389-402.

Gohar Ansari, Z. and K. Aparna. 2017. Identify suitable guar gum genotypes for southern India based on yield and yield attributing traits. Eur. J. Biotechnol. Biosci. 5(6): 32-34.

Gresta, F., O. Sortino, C. Santonoceto, L. Issi, C. Formantici and Y. Galante. 2013. Effects of sowing times on seed yield, protein and galactomannans content of four varieties of guar (Cyamopsis tetragonoloba L.) in a Mediterranean environment. Ind. Crop Prod. 41: 46-52.

Hassan, S. M., A. K. Ei-Gayar, D. J. Cadwell, C. A. Bailey, and A. L. Cartwright. 2008. Guar meal ameliorates eimeria tenella infection in broiler chicks. Vet Parasitol. 157(1): 133-138.

Khademhamzeh, H. R., M. Karimie and A. Rezaie. 2004. Effect of plant density and planting date on agronomic characteristics, yield and yield components in soybean. Iran. J. Agric. Sci. 35: (2). (In Persian with English abstract).

Lakshmi Kalyani, D. 2012. Performance of cluster bean genotypes under varied time of sowing. Agric. Res. Commun. Cen. 35(2): 154-158.

Lone, B. A., B. Hassan, S. Ansar-Ul-hagh and H. Khan. 2010. Effect of seed rate, row spacing and fertility levels on relative economics of soybean (Glycine max. L.) under temperate conditions. Afr. J. Agric. Res. 5(5): $322-324$.

Lopez-Bellido, F. J., R. J. Lopez-Bellido, S. Kasem Khalil and L. Lopez- Bellido. 2008. Effect of planting date on winter kabuli chickpea growth and yield under rainfed Mediteranean conditions. Agron. J. 100(4): 957-964.

Meftahizade, H., Y. Hamidoghli, M. H. Assareh and M. Jaanmard Dakheli. 2017. Effect of sowing date and irrigation regimes on yield components, protein and galactomannan content of guar 


$$
\text { "نشريه علوم زراعى ايران"، جلد بيست و يكم، شماره ז، تابستان 1هسا }
$$

(Cyamopsis tetragonoloba L.) in Iran climate. Aust. J. Crop Sci. 11(11): 1481-1487.

Mendehpour, S., Sh. Lak and M. Sharafizadeh. 2015. The effect of planting date and plant density on phonological characteristics, yield and yield components of hybrid corn Karun 701 in Khuzestan. Crop Physiol. J. 6 (24): 105-118. (In Persian with English abstract).

Nandini, K. M., S. Sridhara, Sh. Patil and K. Kumar, 2017. Effect of planting density and different genotypes on growth, yield and quality of guar. Int. J. Pure Appl. Biosci. 5(1): 320-328.

Patil, D. V. 2014. Genetic variability and sowing dates effect of cluster bean (Cyamposis tetragonolobal. Taub) genotypes in semi arid region of Maharashtra, India. Plant Arch. 14(1):1-6.

Rahmani, T., H. Heidari Sharifabad and H. Madani, 2012. Effect of planting date and comparing yield between red bean cultivars in Ali-Goudarz, Lorestan Iran. New Find in Agric. 6(4): 321-335. (In Persian with English abstract).

Rai, P. S., P. R. Dharmatti, T. R. Shashidhar, R. V. Patil and B. R. Patil. 2012. Genetic variability studies in cluster bean (Cyamopsis tetragonoloba L. Taub). Karnataka J. Agric. Sci. 25(1): 108-111.

Regan, K. L., K. H. Siddique and L. D. Martin. 2003. Response of Kabuli chickpea to sowing rate in Mediterranean type environments of south-western. Aust. J. Exp. Agric. 43: 87-97.

Sasmita, P., R. Ghanashyam Singh and D. Sanat Kumar. 2017. Performance of some promising genotypes of cluster bean (cyamopsis tetragonoloba 1. tabu) under varying levels of primary plant nutrients and row spacing. Int. J. Agric. Sci. 9 (44): 4722-4724.

Satyavathi, P. and M. Vanaja. 2017. Performance of cluster bean (Cyamopsis Tetragonoloba L.Taub.) genotypes under different environmental conditions. 7th International Conference on Innovation in Chemical, Agricultural, Biological and Environmental Sciences. 4-6 December.London, UK.

Sharifi, P., F. Niknami and S. M. Sadeghi. 2016. Effevt of plant density and planting date on yield and yield components of faba bean. J. Agron. Plant Breed. 12 (1): 83-95.

Sharma, P., V. Kumar, K. Venkat Raman and K. Tiwari. 2014. A set of SCAR markers in cluster bean (Cyamopsis tetragonoloba L. Taub) genotypes. J. Biosci. Biotech. 5:131-141.

Singla, S., K. Grover, S. V. Angadi, S. Begna, B. Schutte and S. V. Leeuwen. 2016. Growth and yield of guar (Cyamopsis tetragonoloba L.) genotypes under different planting dates in the semi-arid southern high plains. Am. J. Plant Sci. 7: 1246-1258.

Stacy Lawson Gill, B. S. 2009. Evaluation of reciprocal hybrid crosses in guar. M.Sc.Thesis in Crop Science. Graduate Faculty of Texas Tech University. USA.

Sudhir, S., K. Grover, S., Angadi, B. Schutte, D. Vanleeuwen and D. Auld. 2015. Growth and seed yield performance of promising guar genotypes under different planting dates in desert southwest. $27^{\text {th }}$ Annual Meeting Association for the Advancement of Industrial Crops. October 18-22, Overton Hotel and Conference Center, Lubbock, Texas, USA. 
" اثر زمان كاشت و تراكم بوته بر رشد...مهدى يور و همكاران،

Sultan, M., A. M. Rabbani, Z. K. Shinwari and M. S. Masood. 2012. Phenotypic divergence in guar (Cyamopsis tetragonoloba L. Taub.) landrace genotypes of Pakistan. Pak. J. Bot. 44: 203 - 210.

Taneja, K. D., O. P. Bishnoi, V. U. M. Rao and R. Niwas 1995. Effect of environment on growth and yield of cluster bean. Crop Res. 9: 159-162. 


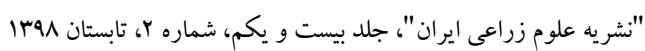

\title{
Effect of sowing time and plant density on growth and seed yield of two guar ecotypes (Cyamopsis tetragonoloba L.)
}

\author{
Mehdipour Afra, M. ${ }^{1}$, M. AghaAlikhani², A. Mokhtassi-Bidgoli ${ }^{3}$ and \\ S. Soufizadeh ${ }^{4}$
}

\begin{abstract}
Mehdipour Afra, M., M. AghaAlikhani, A. Mokhtassi-Bidgoli and S. Soufizadeh. 2019. Effect of sowing time and plant density on growth and seed yield of two guar ecotypes (Cyamopsis tetragonoloba L.). Iranian Journal of Crop Sciences. 21(2):109-126 (In Persian).
\end{abstract}

To evaluate the growth duration and seed yield of two different Guar ecotypes in response to planting time and plant density, a field experiment was conducted in 2016 growing season at the research field of Tarbiat Modares University, Iran. Experimantal factors were arranged as split plot-factorial in a randomized complete block design with three replications. The experimental factors included four planting dates (21 May, 4 June, 21 June and 5 July) assigned to main plots, and factorial combination of three plant densities (130, 200 and 400 thousand plants.ha-1) and two Guar ecotypes (Pakistani and Indian) as sub-plots. The results showed that maximum seed yield (3004.8 kg.ha-1) was obtained from 21 May sowing date and plant density of 130 thousand plants ha ${ }^{-1}$, while in 4 June sowing date, the highest seed yield was harvested from plant density of 200 thousand plants.ha ${ }^{-1}\left(1834.4 \mathrm{~kg} \cdot \mathrm{ha}^{-1}\right)$. There was significant difference for grain yiled between ecotypes in 21 May and 5 June sowing dates. Pakistani ecotype produced highest highest seed yield (2706.1 kg.ha-1) in 21 May sowing date. In the second sowing date (4 June), the Pakistani ecotype produced $32.1 \%$ grain yield more than the Indian ecotype. Pakistani ecotype was superior for seed endosperm percentage (40.5\%) as compared to the Indian ecotype $(38.8 \%)$. In conclusion, sowing of Pakistani ecotype on 21 May with plant density of 130 thousand plants.ha ${ }^{-1}$ had higher seed yield, longer growing duration, taller plant height, higher 1000-seed weight, higher pod number per square meter, dry matter and harvest index. Therefore, it could be suitable for climatic conditions similar to Karaj in Iran.

Keywords: Cluster bean, Guar gum, Plant spacing, Seed endosperm and 1000 seed weight.

\footnotetext{
Received: December 2018 Accepted: February, 2019

1. PhD Student, Tarbiat Modares University, Tehran, Iran

2. Professor., Tarbiat Modares University, Tehran, Iran. (Corresponding author) (Email: maghaalikhani@ modares.ac.ir)

3. Assistant Prof., Tarbiat Modares University, Tehran, Iran

4. Assistant Prof., Environmental Sciences Research Institute, Shahid Behesht University, Tehran, Iran
} 